\title{
O RITMO NA POESIA DE AMORIM DE CARVALHO II. HETEROMETRIA E ISOMETRIA LÍRICA EM VERBO DOLOROSO
}

\author{
Júlio Amorim de CARVAlho
}

Resumen: Análisis exhaustivo de la técnica métrica aplicada, por AMORIM DE CARVALHO, en nueve de las poesías incluidas en la obra Verbo doloroso (1942). Estudio innovador de la ISOMETRÍA y HETEROMETRÍA, en las formas de ritmo lírico del VERSO PENTASILÁBICO (de acentuación par e impar) y HEPTASILÁBICO. La metodología objetiva seguida en este ensayo, la problemática que se plantea, la terminología utilizada, se basan en las LEYES DEL RITMO VERBAL (leyes de la elisión rítmica, de la diálisis rítmica, de las relaciones matemáticas, de la asimilación rítmica, de la partición acentual, etc.) y en múltiples conceptos (ritmo simple y compuesto, verso quebrado y fragmento inicial, ritmo propuesto y efectivo, prolongación paragógica y tiempo vacío en la diálisis rítmica, periodo rítmico y distancia subjetiva en los sistemas de rima y de ritmo, elemento versífico y parástrofa, etc.) formulados en la, o deducidos de la TEORÍA amoriniana DE LA VERSIFICACIÓN que renovó radicalmente el estudio del ritmo verbal y otorgó a la Versificación el estatuto de ciencia.

Palabras clave: acentuación par e impar, Amorim de Carvalho, heterometría, isometría, verso pentasilábico y heptasilábico, teoría de la versificación

Abstract: Exhaustive analysis of the metrical technique applied by AMORIM DE CARVALHO to nine poems included in his work Verbo doloroso (1942). An innovating study of ISOMETRY and HETEROMETRY under the form of lyrical rhythm of the PENTASSYLABIC VERSE (even and uneven accentuation) and HEPTASSYLABIC. The adopted objective methodology in this paper, the proposed problematic, the utilized terminology are 
based in the LAWS OF VERBAL RHYTHM (laws of rhythmic elision, of rhythmic dialysis, of mathematical relations, of rhythmic assimilation, of accent partition, etc.) and in multiple concepts (simple and compound rhythm, broken verse and initial fragment, proposed and effective rhythm, paragogical extension and empty tempo in the rhythmic dialysis, Rhythmical period and subjective distance in the rhymatic and rhythmic systems, versifical element and parastroph, etc.) formulated in or deduced from the Amorinian VERSIFICATION THEORY that radically renewed the study of verbal rhythm and granted to Versification the status of science.

Key words: even and uneven accentuation, Amorim de Carvalho, heterometry, isometry, pentassylabic and heptassilabic verse, versification theory 
Em Poéticas novas todos iguais se copiarão, com mútuas louvaminhas. Eu cantarei, nas leis eternas da Poética, coisas antigas e novas e só minhas. E eles?... Hão-de ler os meus cantos que esconderam, e plagiá-los, e dirão entre si que não me leram.

Amorim de Carvalho, Biografia

$\mathrm{N}$

UM estudo publicado na revista «Rhythmica» ${ }^{1}$, vimos que, nas duas primeiras colectâneas de poesias inéditas e dispersas organizadas por Amorim de Carvalho (Bárbaros, editada em 1927; Destino, editada em 1939), o poeta realizara as suas composições nos dois grandes tipos rítmicos em que se incluem todos os versos simples: o recitativo, único em Bárbaros, e o lírico e o recitativo ${ }^{2}$ em Destino. Deste livro, estudáramos apenas o ritmo lírico. Todo esse trabalho de meticulosa análise rítmica das primeiras poesias publicadas em livro por Amorim de Carvalho, é inovador; foi levado a cabo com a preocupação da máxima objectividade: «unicamente nos interessámos - disséramos nós, então, ao concluir o nosso referido estudo- pelo que, no ritmo verbal, é objectivável». Dentro dos

1 Vid. Amorim de Carvalho, Júlio: "O ritmo na poesia de Amorim de Carvalho". Rhythmica. Revista española de métrica comparada (dirigida por José Domínguez Caparrós e Esteban Torre), Facultad de Filología, Sevilla, 2006, III-IV, 3-4, pp. 7-43.

${ }^{2}$ Conceitos de ritmo recitativo e ritmo lírico in Amorim de Carvalho: Teoria geral da versificação, vol.I. Lisboa: Editorial Império, 1987 (obra citada daqui por diante na forma abreviada: T. g. d. v.), $\mathrm{n}^{\text {os }} 55$ a 60 . -Ulilizaremos, frequentemente, expressões como recitativo e lírico ou forma recitativa e forma lírica ou tipo rítmico recitativo e tipo rítmico lírico para significar o que Amorim de Carvalho chamou ritmo recitativo ou ritmo lírico: tipos de ritmo verbal definidos e desenvolvidamente estudados pelo ilustre teorizador da Versificação. Cf. nosso estudo citado na nota ${ }^{1}$, págs. 24-25.- No presente estudo, nem sempre reformularemos as definições ou nos referiremos desenvolvidamente a conceitos versificatórios já explicitamente evocados no nosso trabalho citado na precedente nota. 
mesmos critérios, trataremos agora do ritmo lírico no terceiro e último volume de inéditos e dispersos que o poeta editou e a que deu o título de Verbo doloroso (1942). Em seguida, voltaremos à análise atenta do ritmo recitativo no qual Amorim de Carvalho compôs a maior parte das poesias dos livros Destino e Verbo doloroso. Recapitulando, teremos:

\begin{tabular}{|c|c|c|c|c|c|c|}
\hline \multirow{3}{*}{ Obras } & \multicolumn{2}{|c|}{ Sonetos } & \multicolumn{3}{|c|}{$\begin{array}{l}\text { Outros sistemas estróficos } \\
\text { lato sensu }\end{array}$} & \multirow{3}{*}{ TOTAIS } \\
\hline & \multirow{2}{*}{$\begin{array}{l}\text { Ritmo } \\
\text { recita- } \\
\text { tivo }\end{array}$} & \multirow{2}{*}{$\begin{array}{l}\text { Ritmo } \\
\text { lírico }\end{array}$} & \multirow{2}{*}{$\begin{array}{l}\text { Ritmo } \\
\text { recita- } \\
\text { tivo }\end{array}$} & \multicolumn{2}{|c|}{ Ritmo lírico } & \\
\hline & & & & $\begin{array}{l}\text { Pentas- } \\
\text { silábico }\end{array}$ & $\begin{array}{l}\text { Heptas- } \\
\text { silábico }\end{array}$ & \\
\hline $\begin{array}{l}\text { Bárbaros } \\
(1927)\end{array}$ & 23 & 0 & 0 & 0 & 0 & 23 \\
\hline $\begin{array}{l}\text { Destino } \\
\text { (1939) }\end{array}$ & 14 & 0 & 22 & $\begin{array}{l}2 \\
\left(5^{1-13-3}\right)\end{array}$ & $\begin{array}{l}7 \\
\left(7^{\infty}\right)\end{array}$ & 45 \\
\hline $\begin{array}{l}\text { Verbo } \\
\text { doloroso } \\
\text { (1942) }\end{array}$ & 6 & 0 & 16 & $\begin{array}{l}2 \\
\left(5^{2} \mathrm{e}\right. \\
\left.5^{1-13-3}\right)\end{array}$ & $\begin{array}{l}7 \\
\left(7^{\infty}\right)\end{array}$ & 31 \\
\hline TOTAIS & 43 & 0 & 38 & 4 & 14 & 99 \\
\hline
\end{tabular}

Das 99 poesias $^{3}$ que compõem os três livros citados no

3 Damos, aqui, à palavra poesia a significação de pequena composição, por oposição a poema onde tema e tese ou conjuntos de temas e teses estão desenvolvidos em longas composições dramatizadas ou não. Dizemos, por exemplo, que se o soneto Alma minha de Camões é uma poesia, Os Lusíadas são um poema; e também, por exemplo, poema é A morte de D. João de Junqueiro, e como tal deverão ser considerados Os simples e a Oração à luz do mesmo poeta. - Ora se, nos três únicos volumes de poesias organizados por Amorim de Carvalho, na primeira metade do século Xx, as duas mais extensas composições não ultrapassam 237 heptassílabos e 9 trissílabos (em «O mistério da vida»), ou 116 versos de heterometria complexa de base rítmica recitativa (em «Tujinha», título que o poeta alterou para «Ainda não te conhecia» quando incluiu esta poesia na Obra poética escolhida), - a criação poética amoriniana teve, como uma das suas características dominantes, a de resultar na realização de extensos poemas épico-filosóficos, desenvolvendo uma rica problemática de temas e teses dramatizados, como Il Poverello, O apóstolo, Paz, A erotíada, O Juizo Final, Elegia heróica, Com Deus ou sem Deus. Mas um poema (longo portanto) pode ser composto em sistemas estróficos geralmente utilizados em poesias (isto é, em composições de reduzida extensão). Temos dois muito originais e muito belos exemplos em Amorim de Carvalho: A comédia da morte, que compreende, essencialmente, 186 sonetos com estrambote, e $O$ amor e 
quadro,apenas 18 foram moldadas em lírico, das quais 9 estão incluídas em Destino e 9 em Verbo doloroso. Note-se que o poeta, a nenhum soneto deu a forma lírica, certamente por admitir que esse sistema estrófico exige um tipo rítmico de toada mais solene, como o recitativo - este tipo rítmico melhor se identificando com a austera temática que, tradicionalmente, é considerada mais própria ao soneto ${ }^{4}$.

Em Destino, Amorim de Carvalho utilizara apenas dois ritmos líricos: o heptassilábico, $7^{\infty}$, de acentuação incerta, e o pentassilábico $5^{1-13-3}$, de acentuação ímpar, -um e outro dentro de modalidades muito regulares, ou sejam, respectivamente: em versos simples heptassilábicos ou compostos bieptassilábicos com cesura, indiferentemente, átona ou tónica ${ }^{5}$; e versos

o tempo composto por 34 sonetos - cada um desses sonetos mantendo, no entanto, sua fisionomia e autonomia próprias.- Amorim de Carvalho nem sempre empregou, em seus trabalhos, as palavras poesia e poema com esta precisão, mas no seu espírito a distinção estava claramente instalada. Vid. T. g. d. v., vol. II, n. ${ }^{\circ} 102$.

${ }^{4}$ No volume II da sua $T . g . d$. v., Amorim de Carvalho estudou longamente o soneto como sistema estrófico «com número fixo de estrofes e formas estróficas fixas», e algumas das suas degenerescências (n. ${ }^{\text {os }} 104$ a 109).

${ }^{5}$ Aproveitamos a oportunidade para rectificar uma afirmação que, a respeito dos heptassílabos de Destino, fizéramos no nosso precedente estudo publicado na revista «Rhythmica», onde escrevêmos que: «Os bieptassílabos [...] foram compostos, indiferentemente, com cesura átona e tónica, esta sem ou com sinalefa» - o que entra em contradição com o que dissemos, acertadamente, algumas linhas mais abaixo: "A indiferente utilização, na mesma composição poética, das cesuras átona e tónica vem do facto que «Em razão da força rítmica dos hemistíquios [heptassilábicos], a cesura tónica [...] não produz elisão rítmica e o ouvido não nota notável diferença entre os compostos de cesura tónica $[. .$.$] e os [...] de cesura$ átona $\left[T . g . d\right.$. v., vol. I, n. $\left.{ }^{\circ} 27\right] »,-$ o que é explicado pela [...] lei da força rítmica». Enunciemos, aqui, de novo, para mais clareza, esta lei, também chamada lei da oposição à elisão rítmica ou da diálise rítmica: "Quanto mais forte musicalidade ou quanto mais força melódica tenha um verso (ou ritmo), mais ele se opõe à sua elisão rítmica com outro verso (ou ritmo), sejam diferentes ou iguais os seus tipos rítmicos» (T. g. d. v., vol. I, n. $\left.{ }^{\circ} 11 \mathrm{~b}\right)$. Exemplifiquemos com quatro daqueles versos de Destino:

E sobre o meu ombro, rindo, | a Lua se debruçou;

E numa voz que amedronta, | e ao mesmo tempo arrebata;

procurando o meu destino, | entre os destinos humanos;

É um castelo sem nome, | a fitar a solidão;

onde, efectivamente, haveria cesura tónica determinada pela elisão rítmica e consequente sinalefa (rin|doa, etc., com ou sem vírgulas), «se à elisão rítmica não se opusesse espontaneamente a diálise rítmica», pois que naqueles versos há a repetição do ritmo muito forte, e, portanto, independente, do componente heptassilábico, «o que o ouvido nota tanto mais facilmente quanto mais dissermos os versos 
compostos bipentassilábicos, de cesura sistematicamente átona, com intercalação, numa das poesias, de 14 pentassílabos (versos simples), na seguinte modalidade estrófica:

$$
\begin{gathered}
5(1)+5 \\
5 \\
5(1)+5 \\
5(1)+5
\end{gathered}
$$

Como no Destino, o poeta incluirá em Verbo doloroso, apenas duas poesias compostas em pentassílabos, que ele intitulou: «Balada do menino» e «Pela noite» ${ }^{6}$. Mas enquanto que naquele

em tom de canto» $\left(T . g . d\right.$. v., vol. I, n. $\left.{ }^{\circ} 11 \mathrm{c}\right)$. Assim, «A diálise ritmica oferece [...] dois aspectos, conforme a estrutura verbal do verso [composto]: o $10^{\circ}$ é o da oposição à sinalefa, pela força rítmica individual dos componentes» ( $E$ sobre o meu ombro, rindo, | a Lua se debruçou); «o 2. ${ }^{\circ}$ é o da separação rítmica, isto é, a não elisão rítmica, na própria cesura tónica, tendendo a um prolongamento tímbrico da tónica, num verdadeiro hiato rítmico» (Por uma noite sem fim $|\ldots|$ o Destino me levou) (T. g. d. v., vol. I, n. $\left.{ }^{\circ} 11 \mathrm{c}\right)$. O membro de frase defeituoso, acima citado, deve corrigir-se como indicamos agora: ... com cesura átona e tónica, esta sem sinalefa à qual se opõe a diálise rítmica. Notemos, aliás, que Amorim de Carvalho, com sua excelente e muito consciente técnica versificatória, põe bem em evidência, pela pontuação (as vírgulas), naqueles quatro versos bieptassilábicos atrás citados, a oposição já de si natural do ritmo heptassilábico à elisão rítmica e, consequentemente, no caso desses versos, à sinalefa.

${ }^{6}$ Apesar do poeta ter atribuído o título de balada à primeira destas composições poéticas, essa denominação se afasta dos conceitos de balada estudados desenvolvidamente por Amorim de Carvalho na T. g. d. v., vol. II, n. ${ }^{\text {s }} 117$ e 118, como também não coincide com a definição que demos de balada na nota ${ }^{38}$ do estudo precedentemente publicado na «Rhythmica». Estaríamos, então, agora, em presença de um terceiro conceito, já bastante diluído, de balada que se alargaria a uma composição poética que gerasse, no espírito do leitor, uma stimmung, digamos, uma atmosfera, onírica ou de devaneio, através de interrogação metafísica, por meio de temas de grande simplicidade em formas métricas muito cantantes (ritmos de tipo lírico), com exclusão do eneassílabo tripartido, $9^{36}$, porque este ritmo impõe uma rigidez cíclica, de curta frequência, emprestando à expressão verbal um alor marcial: tatatátatatátatatáta, tatatátatatátatatá,

Quando ao longe, nos campos d'Arzila, alvejava do mouro o albornoz,

Portugal, ó leão do ocidente tu rugias à beira do mar,

(Alexandre Herculano) 
É certo que se lhe pode imprimir um cambiante filosófico, como, ainda em Alexandre Herculano:

No mosteiro vai fundo o silêncio; um silêncio que gera terror;

Caia em pó o mosteiro; e maldito o que erguê-lo outra vez intentar, se não treme ante as nuas caveiras, que insepultas verá branquejar!

e mesmo de vago impressionista no gôsto mallarmeano:

Pelas margens dos olhos vazios

a correr em galopes esguios

vão cavalos de tempo nos rios.

Saberei o que sabem os sábios

dos países sem olhos nem lábios

\section{(Natércia Freire)}

O cunho marcadamente cíclico, de frequência curta, do eneassílabo tripartido, prestou-se a que o poeta brasileiro Nilo Tacques Soares evocasse, numa curiosa poesia, composta nesse ritmo, o passar inexoràvelmente irreversível do tempo:

Sou o tempo que passa, que passa,

Sem princípio, sem fim, sem medida,

Vou levando a ventura e a desgraça,

Vou levando as vaidades da vida.

A correr de segundo em segundo

Vou formando os minutos que correm.

Formo as horas que passam no mundo,

Formo os anos que nascem e morrem.

Ninguém pode evitar os meus danos,

Vou correndo sereno e constante.

Dêste modo de cem em cem $a$ nos

Formo um século e passo adiante.

mas sempre com aquela coloração marcial, à qual já se adapta excelentemente a base trissilábica, em sua forma regular, como neste belíssimo poema heróicorevolucionário da autoria do grande ritmista romântico que foi António Pinheiro Caldas:

Quando a morte cruenta que ao longe negreja

Me faça gelar; 
primeiro livro, Amorim de Carvalho não utilizara senão, como vimos, o pentassílabo de acentuação ímpar ( $\left.5^{1-13-3}\right)$, já no segundo livro referido vai ele apelar para os dois ritmos pentassilábicos: o de acentuação par $\left(5^{2}\right)$ e o de acentuação ímpar. Estes ritmos, de «relações matemáticas complexas», como logo se verifica procedendo ao seu «desdobramento estrutural» expresso na «fórmula analítica» $\left(5^{2}=<2+3>; 5^{1-13-3}=\right.$, respectivamente, $<1+4>,<1+2+2>,<3+2>$ ), «não combinam bem [...] entre si $\rangle^{7}$.

$A$ atenção dada pelo poeta às leis do ritmo e a agudeza de seu ouvido, obstaram a que ele entremeasse, desgraciosamente, numa mesma composição poética, os pentassílabos de acentuação par e ímpar, destruindo, deste passo, a harmonia rítmica. $\mathrm{Na}$ «Balada do menino» optou pela acentuação par $\left(5^{2}\right)$ que não pode, para que o verso saia escorreito, senão incidir na $2 .{ }^{\text {a }}$ sílaba: $2 .^{\mathrm{a}}$

Também eu iria em doidas viagens,

Eu não quero que os homens nos seios da terra Me vão sepultar.

21-24-27-30-

$33-36$

Eu não posso na patria - que opprimem tyrannos -

$39-42-45-48-$

Em paz descansar.

$51-54$

Este ritmo - ao qual dificilmente se adaptarão os conceitos de balada acima descritos - nunca atraiu Amorim de Carvalho. - A poesia «Pela noite» poderia também ficar incluída naquela ideia, já muito vaga, por nós sugerida, de balada.

${ }^{7}$ T. g. d. v., vol. I, n.os 12c, 63 («Canónica das combinações heterométricas»). Vid., tb., a nota 11 do nosso citado estudo publicado na revista Rhythmica, 2006, IIIIV, 3-4 . - As fórmulas analíticas e sintéticas da «notação numérica» dos versos simples e compostos, foram descobertas e generalizadas a todos os ritmos verbais por Amorim de Carvalho. Este excelente método, perfeitamente inteligível, está largamente exemplificado, pelo seu inventor, em diversas obras suas. No referido estudo publicado na revista «Rhythmica», por querermos estabelecer máxima e imediata clareza na distinção dos versos simples e compostos, propusemos os sinais $<>$ para indicar, na notação numérica, a fórmula analítica dos versos simples. Assim, um pentassílabo de acentuação par (verso simples) terá a seguinte fórmula analítica: $<2+3>$; um bipentassílabo (verso composto) de cesura tónica, cujos componentes tenham a mesma acentuação, ver-se-á atribuir a seguinte fórmula analítica: $<2+3>+<2+3>$, - correspondendo, respectivamente, às fórmulas sintéticas: 52 e $52+52$. Se o primeiro componente do verso composto tiver cesura átona, a fórmula analítica será: $<2+3(1)>+<2+3>$, que corresponde à fórmula sintética: $5(1) 2+52$. A fórmula sintética é, pois, geralmente enriquecida com um expoente, $o$ que, para os versos de acentuação incerta se indica deste modo: $6 \infty, 7 \infty$. 
por longes paragens!

Iria à procura

de raros tesoiros!...

porque, se a $4 .^{\text {a }}$ sílaba tivesse forte tonicidade própria ou natura ${ }^{8}$, estaríamos perante os casos imperfeitos já por nós longamente estudados, a propósito de dois versos heptassilábicos, com dupla acentuação final, do livro Destino ${ }^{9}$. Mas estas situações não aparecem nos pentassílabos da «Balada» de Verbo doloroso. Se quizéssemos ser excessivamente meticuloso, podíamos apontar o verso:

que em sonhos não ande,

onde a relativamente fraca acentuação da $5 .{ }^{\mathrm{a}}$ sílaba $(a n)$ poderia sujeitar-se à concorrência da forte tonicidade de não (4. ${ }^{\mathrm{a}}$ sílaba), numa dupla nasalação sem expressiva harmonia. Mas a leitura desprevenida do verso leva a que a sílaba não se atonize em ligação proclítica com o acento rítmico terminal (não $\rightarrow$ ande), numa acomodação ao ritmo efectivamente realizado nesta composição poética, - o que será um caso explicado pela lei da subordinação ou assimilação rítmica:

Qual é o menino | que nunca delira?

que em sonhos não $\rightarrow$ ande

absorto no sonho...

onde se dá inevitàvelmente «o abrandamento e a próclise rítmica» da tónica não rítmica ${ }^{10}$.

Em certos hemistíquios da mesma «Balada», encontram-se casos como estes:

\footnotetext{
${ }^{8}$ Para o conhecimento dos interessantíssimos conceitos de tonicidade própria ou natural e de tonicidade posicional (em certa medida por oposição à precedente), Vid. T. g. d. v., vol. I, n.os 4 e 21.

${ }^{9}$ Vid. revista Rhythmica, 2006, 3-4, pp. 37-38.

${ }^{10}$ Cf. T. g. d. v., vol. I, n. ${ }^{\text {s }} 68$ e 69 ; e nosso estudo publicado na revista Rhythmica, 2006, III-IV, 3-4, págs. 18-19, incluindo a nota ${ }^{26}$ na qual transcrevêmos a lei formulada por Amorim de Carvalho.
} 
tão meiga tortura...;

Quando eu fôsse grande... [cinco vezes na poesia];

Quando eu já fôr grande...;

pois foi só dos outros...;

de ser homem feito;

E quem não terá...;

que, se levássemos a análise a profundas meticulosidades, podiam também encontrar explicação no âmbito da lei da subordinação rítmica. As sílabas com valor rítmico (a 2. ${ }^{a}$ em cada hemistíquio) são mais fracas do que algumas das que lhes estão justapostas (tónicas não rítmicas): tão mei, Quando eu fô, Quando eu já, foi só, ser ho, quem não. Ora, fora do contexto rítmico efectivo da poesia, nós acentuaríamos naturalmente as sílabas de mais forte tonicidade (tonicidade própria ou natural); porém, a boa leitura, tecnicamente perfeita, imposta pela lei da subordinação rítmica, exige que as sílabas mais fracas (mei, do eu, foi, ser, quem) não sejam enclítica nem procliticamente atraídas pelas que lhes estão justapostas; pelo contrário: serão as sílabas de mais débil acentuação que deverão ser bem marcadas na dicção, por exigência rítmica resultando da sua posição no ritmo - o pentassilábico $5^{2}$, isto é, de acentuação par -, ritmo proposto pelo poeta e por ele efectivado na composição poética $^{11}$ : é que essas sílabas adquirem, naquelas condições, uma

${ }^{11}$ Conceitos de ritmo proposto e ritmo efectivo : Vid. T. g. d. v., vol., I, n. ${ }^{\circ}$ bb. Cf. a referência que fizemos a estes importantíssimos conceitos amorinianos, no precedente estudo que publicámos na Rhythmica, 2006, III-IV, 3-4, nota 35 e texto correspondente na p. 23. - Esta nota proporciona-nos a ocasião de formular uma observação necessária. A teoria da Versificação, construída por Amorim de Carvalho, tem sido ignorada em Portugal. Foi, afinal, um estrangeiro, o professor José Domínguez Caparrós, da Universidade de Madrid, o primeiro a desenvolver um apanhado da teoria do verso elaborada pelo esteta português. $\mathrm{O}$ trabalho deste universitário - estudo comparativo, valorizando a obra de Amorim de Carvalho, subordinado ao título "La teoría del verso de Amorim de Carvalho. Notas de lectura" - foi lido no colóquio realizado no Porto, em 2004, para comemorar o $1 .^{\circ}$ Centenário do nascimento do intelectual português; está agora publicado in Domínguez Caparrós, José: Nuevos estudios de métrica (Madrid: Universidad Nacional de Educación a Distancia, 2007), uma colectânea de excelentes ensaios dispersos ou inéditos da autoria do ilustre metricista espanhol. Nesse estudo, o professor Domínguez Caparrós atenta, precisamente, nos conceitos de ritmo proposto e ritmo efectivo que parecem tê-lo particularmente interessado. Mas também aborda certos outros aspectos fundamentais da teoria amoriniana, como a tonicidade posicional da sílaba, a elisão rítmica e a diálise rítmica, a terminação falsa do verso, 
«tonicidade rítmica posicional», conforme explica a lei da tonicidade posicional: "O lugar de acentuação rítmica num verso [ou ritmo] reforça por si a tonicidade própria [fraca, nos casos aqui estudados] da sílaba nesse lugar» ${ }^{12}$. Donde se deduz que, como ensina a lei da exigência de fôrça tónica do acento rítmico, a «exigência da tonicidade própria ou natural dos acentos rítmicos principais é tanto maior quanto mais concorra uma acentuação rítmica secundária ou uma acentuação não rítmica»» ${ }^{13}$ (nos casos aqui analisados, não rítmica, concorrendo fortemente as sílabas: tão, Quan, fô, já, só, ho, não): mas não podemos dizer que, nestes hemistíquios da «Balada», Amorim de Carvalho solicite, inestèticamente, essa tonicidade posicional, pois as sílabas mei, do eu, foi, ser, quem, possuem já certa tonicidade própria ou natural (ou como tal se revelam em dicção espontânea), o que as faz inserirem-se, sem artificialidade, na correnteza duma leitura que respeite a toada própria do ritmo efectivado na poesia.

Em contraponto ao que acabamos de expor, exemplificaremos com outros dois membros de versos compostos da mesma poesia:

$$
\begin{aligned}
& \text { com quem eu namoro...; } \\
& \text { em que eu, da janela... }
\end{aligned}
$$

Neles, a tonicidade própria (embora relativamente fraca) das

as características de diversos ritmos e os conceitos de verso elementar e quebrado, etc. Ora, toda esta problemática, conhecida, aceite ou discutida no estrangeiro, parece não interessar os literatos portugueses. É certo que em Portugal (país, no entanto, de riquíssima cultura poética) nunca surgiram, com a notável excepção de Amorim de Carvalho, verdadeiros especialistas destas questões. Grande interesse pela T. g. d. v. de Amorim de Carvalho demonstrou (embora com certas afirmações contestáveis) Vera Vouga, que publicou extensa recensão dessa obra na Revista da Faculdade de Letras. Línguas e Literaturas, 1990, II série, VII, (de que se tirou separata). Já sobre a estética amoriniana em geral, citaremos, in Amorim de Carvalho: Estética e teoria da arte (Porto: Estratégias criativas, 2004), as "Breves notas sobre a teoria estética e artística de Amorim de Carvalho" da autoria do Professor Doutor Artur Manso, espírito independente e lúcido, que nelas se refere, com alguma insistência, ao conceito amoriniano de poesia.

${ }^{12}$ Para a explicação de um fenómeno rítmico, podem concorrer, e concorrem frequentemente, mais do que uma lei. Para o caso aqui tratado, concorrem, pelo menos, a lei da tonicidade posicional e a lei da subordinação rítmica ou assimilação rítmica (Vid. T. g. d. v., vol. I, n. ${ }^{\circ} 68$ in limine, 68a,d).

${ }^{13}$ Vid. T. g. d. v., vol. I, n. ${ }^{\circ} 21$ e (formulação da lei), 21 a (conceitos de tonicidade própria ou natural e tonicidade rítmica posicional). 
sílabas que ocupam posição «de acentuação rítmica» (quem, que eu) não sofre concorrência premente das sílabas com, eu, em, $d a$, as quais, justapostas àquelas, e não preenchendo «lugar de acentuação rítmica», também não possuem forte ou nem mesmo nenhuma tonicidade própria.

Noutros raríssimos momentos, encontram-se na «Balada» relações acentuais como:

Iria à procura [pronúncia corrente: Irià...]; qual água do rio...;

Qual é o menino...;

onde os acentos não-rítmicos ( $a \grave{a}, q u a l)$ têm, praticamente, fôrça tónica equivalente aos acentos rítmicos. Estes casos, aqui excepcionalíssimos, seriam, talvez, de evitar. Como diz lapidarmente Amorim de Carvalho na T. g. d. v., «Considerados os versos [...] na sua pureza rítmica, esta existe quando impõe uma toada própria inequívoca [...] [na] dicção espontânea e corrente»; «a boa técnica exige [...] que a acentuação rítmica [...] seja inequívoca [...]. Do contrário, temos versos menos perfeitos pela concorrência possível, na dicção espontânea», de acentos de divergente orientação rítmica ${ }^{14}$. No entanto, dada a extrema raridade destes casos na poesia presentemente estudada, e considerando o fenómeno dominador explicado pela lei da subordinação ou assimilação rítmica num longo conjunto de versos de grande perfeição rítmica, a dicção faz-se espontaneamente sem que o ouvido retenha significativamente a tonicidade forte ou relativamente forte de certas sílabas ímpares dos casos acima transcritos. Ao evocar esta problemática, a propósito da «Balada» incluída em Verbo doloroso, fomos, certamente, exigentes em demasia.

Abordemos agora outro aspecto da versificação da «Balada do menino», o qual, apesar de não se referir propriamente ao ritmo verbal, irá servir de preliminar ao estudo de certas modalidades da metrificação pentassilábica de Amorim de Carvalho. A «Balada» é constituída por oito parágrafos poéticos, que podíamos chamar parástrofes ${ }^{15}$, de formas variáveis, isto é, com

$\overline{{ }^{14} T .}$ g. d. v., vol. I, n. ${ }^{\circ} 20 \mathrm{~d}, \mathrm{e}$.

${ }^{15}$ Do grego pará-strophe, ao lado da estrofe, que se aproxima do conceito de estrofe, 


\section{número desigual de elementos versíficos ${ }^{16}$ que se distribuem}

mas nele se não inclui perfeitamente, que aponta para a estrofe mas é dela discordante. - Conceito amoriniano de parágrafo poético. Diz o ilustre teorizador da Versificação que «Por vezes o poeta estabelece diferentes e arbitrárias separações que estão fora do conceito de estrofe, dando-nos tiradas de diferentes extensões, a que podemos chamar parágrafos poéticos» (T. g. d. v., vol. II, n. $\left.{ }^{\circ} 102\right)$. Amorim refere-se às «arbitrárias separações» por oposição à rigidez pré-estabelecida das estrofes tradicionalmente consagradas, mas não por oposição àquelas separações que, nas composições poéticas, correspondem aos parágrafos da prosa, isto é, às separações de um ou mais períodos tratando todos eles de um mesmo assunto ou de um assunto relativamente unificado, em comparação com outros do mesmo texto. Nestes casos, e por essa mesma unidade temática, não estamos em presença de «arbitrárias separações»; e a essas separações não arbitrárias poderíamos dar o nome de parástrofes. Mas há, efectivamente, casos evidentes de «arbitrárias separações», como, por exemplo, no livro Petites légendes (Paris, 1949), de Maurice Carême, nas poesias L'amoureux:

Elle venait de naître
D'un friselis de vent,
Elle venait de rire
Si naturellement

Que c'est lui, brusquement,

Qui ne fut plus qu'un rêve

Etonné d'être là,

Seul, à l'orée du bois.

\section{e Brouillard d'automne:}

Le voici brouillard à son tour

Et se penchant avec amour,

Le voici prenant dans ses bras

L'enfant seul qui joue sans l'entendre,

Et comprenant soudain pourquoi,

Dans les automnes d'autrefois,

Le brouillard lui semblait si tendre.

${ }^{16}$ Elemento versífico ou metrífico são expressões nossas. Exprimem a ideia duma forma verbal que se relaciona, de qualquer modo, com o verso (ou metro) sem que, nessa mesma forma tomada isoladamente, seja forçosamente verso para o conjunto rítmico da composição poética a que pertence. O elemento versífico é o que se relaciona com a metrificação. Não diz, pois, respeito às formas poéticas ritmicamente desordenadas ou não metrificadas que foram estudadas por Amorim de Carvalho in $T$. g. d. v., vol. II, n. ${ }^{\text {os }} 126$ a 130 (cap. "O verso livre»). - Quando o poeta escreve, numa poesia de ritmo pentassilábico, $5^{2}$ :

meus olhos seguiam, por entre os que vêm, por entre os que vão, aquela

menina que nem escutava 
como se segue: 1 . $^{a}$ parástrofe ou parágrafo poético, 10 elementos versíficos; 2. ${ }^{\mathrm{a}}$ parástrofe, $2 ; 3 .^{\mathrm{a}}, 25 ; 4 .^{\mathrm{a}}, 6 ; 5$. $^{\mathrm{a}}, 14 ; 6 .^{\mathrm{a}}, 1 ;$. $^{\mathrm{a}}, 2$; 8., , 5. É por esta mesma variabilidade, que nem Amorim nem nós consideramos estar, aqui, em presença de estrofes ou estâncias cujos conceitos implicam estruturas regulares ritmo-lógicas e até rimáticas ${ }^{17}$. Em Amorim de Carvalho, as parástrofes das

\section{(Amorim de Carvalho)}

podemos hesitar em chamar verso a «aquela», na segunda linha do texto transcrito. No entanto, «aquela» relaciona-se com o ritmo conscientemente imposto, pelo autor, à sua composição poética, está em coerência rítmica com o conjunto poético, não é elemento sem significação rítmica, porque entra num todo mais vasto: «aquela menina» que é um pentassílabo 52, ritmo efectivado na poesia. Se o elemento em causa não tivesse sentido rítmico para esta; se, por exemplo, alguém redigisse isto:

meus olhos seguiam, por entre os que vêm, por entre os que vão, essa

menina que nem escutava

então «essa» não se comportaria como elemento versífico, mas, por sua ininteligibilidade para o conjunto rítmico, seria um simples elemento abstruso, inassimilável pela razão rítmica na qual não se integraria. (Veremos, adiante, no entanto, que «aquela» é um quebrado do 52, o que já permitirá considerar este elemento versífico como autêntico verso, verso quebrado: T. g. d. v., vol. I, n. ${ }^{\circ} 23$; Vid., tb., n. ${ }^{\circ}$ 63: «Canónica das combinações heterométricas»). Amorim de Carvalho, na sua T. g. d. v., dá-nos (extraído do início do seu belíssimo poema O Juízo Final) um excelente exemplo do que nós consideramos elemento versífico mas não verso:

Jesus foi preso. E Pilatos, para salvar

o mago

e rei de não se sabe que céu confuso e vago,

a todos perguntou: - «Quem é que vós quereis crucificar?...»

A respeito da primeira linha do texto acima, tomada na sua globalidade, por si só, não tendo nenhuma ou tendo diminuta inteligibilidade rítmica para o conjunto poemático considerado, - a respeito dessa linha que abre o poema, diz Amorim de Carvalho: «lid[a] isoladamente, é [do ponto de vista rítmico] simplesmente detestável». Não a chamaremos, pois, de verso. É um elemento versífico, que surgiu "por determinação rimática», resultado de subtil técnica de construção e exigindo subtil técnica de dicção para sua integração no todo rítmico do poema (cf. T. g. d. v., vol. I, n. ${ }^{\circ} 89$, onde se definem e estudam longamente os versos de determinação rítmica e de determinação rimática):

Jesus foi preso. | E Pilatos | para salvar

o mago $\|$

$4(1)+3(1)+4$

e rei de não se sabe | que céu confuso e vago, ||

2(1)

a todos perguntou: $\mid-$-Quem é que vós quereis crucificar? » $\| 6+10^{6}$

${ }^{17}$ Não entraremos em detalhes. Original e exaustivo estudo do conceito de estrofe se encontra na $T$. g. d. v., vol. II, n. ${ }^{\text {os }} 95$ a 123. 
suas poesias prefiguram, desde Destino (1939), as separações de carácter lógico, embora diversamente extensas, que o poeta estabelecerá nas longas narrações épico-filosóficas dramatizadas de alguns dos seus poemas ${ }^{18}$.

Ora, se a «Balada» se desenvolve através duma construção heterométrica, - o certo é que esta composição está, na realidade, submetida a uma regularidade métrica rigorosa: é que os 65 elementos versíficos que vimos formarem a poesia estudada, correspondem (ou podiam corresponder ${ }^{19}$ ) rigorosamente a 105 pentassílabos. Vejamos a feição geral que, desse ponto de vista, o poeta imprimiu à «Balada», transcrevendo, por exemplo, partes das $1 .^{\mathrm{a}}$ e $3 .^{\mathrm{a}}$ parástrofes, a $4 .^{\mathrm{a}}$ na totalidade e parte da 5. a.

Eu fui o menino | que pouco brincava, e só em ser grande, | ansioso, pensava. |

Eu lia

poemas | que mal entendia; |

mas lendo-os sentia, |

bem dentro de mim,

tão meiga tortura, | profunda e secreta! |

Meus olhos sonâmbulos | ficavam-se a olhar |

navios perdidos | nas ondas do mar! |

Quando eu fôsse grande, | iria ao Brasil... |

Ó minha

mãezinha,

não chores, que eu volto! | Eu hei-de voltar |

Onde é que tu vives, | menina pobrinha |

com quem eu namoro, | brincando contigo | no sonho

risonho |

da minha quimera? | Quimera tão grata! |

Quando eu já fôr grande, | tu hás-de ser minha, |

e eu hei-de vestir-te $\mid$ de rendas de prata... $\mid$

Às vezes, à hora | em que eu, da janela, |

as ruas olhava, |

meus olhos seguiam, | por entre os que vêm, | por entre os que vão, |

${ }^{18} \mathrm{Vid}$., neste ensaio, em uma nota anterior, as considerações que fizemos a respeito da diferença entre poesia e poema. Consultar, tb., sobre esta distinção terminológica, o n. ${ }^{\circ} 102$ do vol. II da T. g. d. v.

${ }^{19}$ Mostraremos, mais à frente, as razões desta reserva que diz respeito a quatro casos métricos da «Balada». 
aquela

menina $\mid$ que nem escutava $\mid$

o grito que eu tinha | no meu coração, |

chamando por ela... |

Há, aqui, inovação certa na obra poética de Amorim de Carvalho publicada em livro.

$\left.1 .^{\circ}\right)$ Como vimos no quadro atrás, o ritmo $5^{2}$ é por ele pela primeira vez empregue, em livro, neste Verbo doloroso que inclui a «Balada do menino». E, se no livro Destino, o poeta intercalara com rígida regularidade, o pentassílabo com o bipentassílabo (mas, neste caso, como também vimos, de acentuação ímpar, $\left.5^{1-13-3}\right)$, - naquela «Balada» o poeta intermeia, já sem ordenação pré-estabelecida, em plena liberdade, o pentassílabo com versos bipentassilábicos e tripentassilábicos ${ }^{20}$. Mas insistimos: nunca Amorim de Carvalho introduz o ritmo pentassilábico de acentuação ímpar de mistura com o de acentuação par; caso contrário, seria cometer êrro de consequências rítmicas desastrosas. Um ouvido educado rejeita-o sem hesitação. A toada própria do ritmo $5^{2}$ é, pois, sustentada, com a máxima naturalidade, ao longo da poesia, - mesmo naqueles raros casos, por nós analizados (talvez com excessiva e até ilegítimo espírito perfectivo), que se enquadram, aliás, sem artificialidade marcante na lei da tonicidade posicional.

$\left.2 .^{\circ}\right)$ Os ritmos pentassilábicos foram, indiferentemente, escritos com terminação grave ou aguda: $5(1)^{2}$ ou $5^{2}$. Os bipentassílabos e os tripentassílabos têm, portanto, também, indiferentemente, cesura átona (átona simples $5(1)^{2}+5^{2}$, e, num único verso, dobrada $5(2)^{2}+5^{2}$ :

Meus olhos sonâmbulos | ficavam-se a olhar)

ou tónica $\left(5^{2}+5^{2}\right)$. O que o poeta tem bem no ouvido é o ritmo muito forte do pentassílabo $5^{2}$. Ele não se atarda, pois, com formalismos ritmicamente inconsequentes ou fundamentalmente

\footnotetext{
${ }^{20}$ Sobre o ritmo pentassilábico, $\mathrm{Vid}$. os muito desenvolvidos e definitivos estudos de Amorim de Carvalho in T. g. d. v., vol. I, n.os 11c, 20, 30, 31, 55a, 57, 58, 60, 61, 62e,g, 63 («Canónica das combinações heterométricas»), 68d, 69d4, 69e,f.
} 
inconsequentes, - porque «a individualidade musical do pentassílabo» «se opõe à sua elisão rítmica com outro verso (ou ritmo), sejam diferentes ou iguais os seus tipos rítmicos» ${ }^{21}$; eis a razão pela qual Amorim não hesita em escrever, na sua «Balada», versos como estes:

e só em ser grande, | ansioso, pensava;

Quando eu fôsse grande, | iria ao Brasil;

Âs vezes à hora $\mid$ em que eu, da janela;

onde uma falsa compreensão do ritmo pentassilábico poderia induzir a fazer sinalefa:

... gran $\mid$ de, ansioso ...

... gran $\mid$ de, iria ...

... ho | ra em...

quando, na realidade, este ritmo leva, espontaneamente, «a fazer hiato contra a sinalefa, ou a fazer silêncio de pausa enfática, ou como que um prolongamento paragógico de ritmo quando o verso antecedente é agudo», não resultando «o efeito da elisão rítmica», «havendo até tendência separativa $[. .$.$] para a cesura$ átona $\rangle^{22}$ :

Havia um país, $|. .$.$| além no oceano...;$

... por entre os que vêm, $|. .$.$| por entre os que vão;$

E quem não terá, $|. .$.$| no imo do peito;$

a mágoa cruel $|. .$.$| do louco menino...$

num «silêncio de pausa enfática com valor métrico de completação, de preenchimento, a corresponder ao tempo vazio [...] que, em notação numérica, indicaríamos [...] [por] $\left.5(0)^{2}+5\right\rangle^{23}$. De contrário, e lidas duas a duas as formas pentassilábicas, o ritmo ficaria até contrafeito.

\footnotetext{
${ }^{21}$ Vid. T. g. d. v., vol. I, n.os 11b, 20f. Cf., tb., a enunciação da lei da oposição à elisão rítmica na nota 5 deste estudo.

${ }^{22}$ T. g. d. v., vol. I, n.os 20f, 30c ; Vid. cesura nos n.os 7, 8, e leis da elisão rítmica e da oposição à elisão rítmica ou da fôrça rítmica ou da diálise rítmica ou do hiato rítmico no $\mathrm{n} .^{\circ} 11 \mathrm{a}, \mathrm{b}$.

${ }^{23}$ T. g. d. v., vol. I, n. ${ }^{\circ} 30 \mathrm{c}$.
} 
$\left.3 .^{\circ}\right)$ Assunto interessante é o de saber se, efectivamente, bipentassílabos e tripentassílabos (versos compostos) representam ritmos específicos, com, pelo menos, certa individualidade em relação ao pentassílabo (verso simples). Sendo o ritmo pentassilábico muito forte, opondo-se, consequentemente, à elisão rítmica (como já bastas vezes dissemos), - poder-se-ia admitir que a forma composta bipentassilábica (com ou sem cesura átona) não fosse, ritmicamente diferente da de dois pentassílabos lidos sucessivamente. Por exemplo, os versos:

Meus olhos sonâmbulos ficavam-se a olhar navios perdidos nas ondas do mar!

Havia um país, além do oceano,...

seriam ritmicamente idênticos a:

Meus olhos sonâmbulos

ficavam-se a olhar

navios perdidos

nas ondas do mar!

Havia um país,

além do oceano,...

Não é esse o caso. Porque a forma bipentassilábica introduz, espontâneamente, uma dicção mais seguida do conjunto dos hemistíquios, enquanto que os pentassílabos isolados levam, em si, as condições de uma leitura mais separativa de uns para os outros. São, pois - o pentassílabo e o bipentassílabo - dois ritmos já algo diferenciados, mas sem dúvida que a «toada própria do verso composto participa da dos seus componentes» ${ }^{24}$. No composto tripentassilábico, poder-se-á detectar uma forma rítmica que também lhe é específica. Leiam-se naturalmente os cinco tripentassílabos seguintes que o poeta incluiu, nessa precisa forma, na «Balada»:

Havia um país, além do oceano, chamado Brasil.

Virei muito rico! Navios, navios que andavam no mar,

$\overline{{ }^{24} T .}$ g. d. v., vol. I, n. ${ }^{\circ} 24 \mathrm{~b}$. 
meus olhos seguiam, por entre os que vêm, por entre os que vão,

qual água do rio que estende e se espraia no fundo do vale,

a mágoa cruel do louco menino que nunca foi grande?...

A dicção é, se natural, forçosamente diferente da dos versos simples:

Havia um país, além do oceano, chamado Brasil.

Virei muito rico!

Navios, navios

que andavam no mar,

etc.

porque o finalizar de um verso implica, ou sugere, na maneira de dizer, a espontaneidade de um «descaímento suave da voz para o silêncio» ${ }^{25}$. A leitura de:

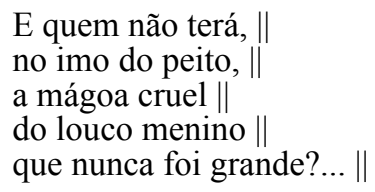

onde as duplas barras indicam a suspensão, o «descaímento», a finalizarem com naturalidade cada um dos versos simples, - essa leitura, dizíamos, se diferencia indiscutivelmente da de:

E quem não terá, | no imo do peito, || a mágoa cruel | do louco menino | que nunca foi grande?... ||

também com a mesma suspensão, o mesmo «descaímento», a finalizarem os versos, mas já se distinguindo, entre si, as duas formas (a bipentassilábica e a tripentassilábica) numa dicção,

$\overline{{ }^{25} \text { Vid }}$. o que Amorim de Carvalho expõe, muito a propósito, sobre a dicção da parte terminal do verso in T. g. d. v., vol. I, n. ${ }^{\circ} 3$. 
naturalmente mais seguida dos componentes de cada um destes versos compostos: «A noção de ritmo é essencialmente psicológica, subjectiva, porque resulta da apreensão perceptiva e estética duma certa sucessão de fenómenos coerentemente ligados num todo com regularidade (ritmo efectivo) ou com irregularidades que seriam repetíveis com agrado estético (ritmo proposto) ${ }^{26}$. Assim, os ritmos bipentassilábico e tripentassilábico (ritmos efectivos) resultam duma sucessão regular do ritmo proposto pentassilábico. Apesar da diálise rítmica exigida, como se sabe, pelo ritmo pentassilábico, o todo do verso composto bipentassilábico ou tripentassilábico desenha uma continuidade rítmica própria a cada um deles. $\mathrm{O}$ entremear versos simples (pentassílabos) e compostos (bipentassílabos e tripentassílabos), sugerindo, deste modo, numa dicção que seja espontânea, ligeira diferenciação rítmica, embora dentro (como não podia deixar de ser) da mesma estrutura rítmica, $5^{2}$ (a «toada própria do verso composto - não o esqueçamos - participa da dos seus componentes»), - empresta à poesia uma ligeireza que, quebrando a uniformidade na maneira de dizer, só valoriza os aspectos melódicos da composição ${ }^{27}$. No entanto, os elementos versíficos que fossem mais longos que os trímetros pentassilábicos, constituiriam já agrupamentos que o ouvido não poderia, ou dificilmente poderia reter como um todo coerente, que o ouvido não apreenderia com agrado, não dando significado rítmico claro ao conjunto daquelas extensões verbais. $\mathrm{O}$ conceito de verso restabelecer-se-ia, nesses casos (por exemplo, um quadripentassílabo), em formas de agrupamento mais reduzido (dois bipentassílabos, ou um tripentassílabo e um pentassílabo) susceptíveis de serem

$\overline{{ }^{26} T .}$ g. d. v., vol. I, n. ${ }^{\circ} 11 \mathrm{~d}$.

${ }^{27}$ A dicção dos versos terá, pois, nuanças na abertura das pausas ou suspensões ou prolongamentos paragógicos que, dos mais breves aos mais longos, poderiam, em teoria, ordenar-se como indicamos: corte rítmico (que «parece interceptar o todo musical do verso», sem interferir no ritmo: Vid. T. g. d. v., vol. I, n. ${ }^{\circ}$ 5b), cesura, suspensão ou «descaímento» ou pausa final do verso. É claro que esta sistematização das pausas, prolongamentos sónicos, suspensões, na maneira de dizer os versos (na qual interferem, também, os casos da terminação falsa - o que, muito sugestivamente, se chama, em castelhano, encabalgamiento), tem, em sua objectividade, muito de subjectivo, como se exprimiu Amorim de Carvalho, e como este esteta cuidadosamente explicou no prefácio da T. g. d. v., vol. I, págs. 10-11. 
abarcadas, com naturalidade e com agrado, pelo sentido auditi$\mathrm{vo}^{28}$.

4. ${ }^{\circ}$ ) Importante inovação de Amorim de Carvalho na sua poesia de ritmo lírico, surge, no livro Verbo doloroso, com as desarticulações ${ }^{29}$ de versos em elementos versíficos de determinação rimática ${ }^{30}$. Na «Balada» aqui estudada, encontramos quatro dessas situações que passamos a transcrever:

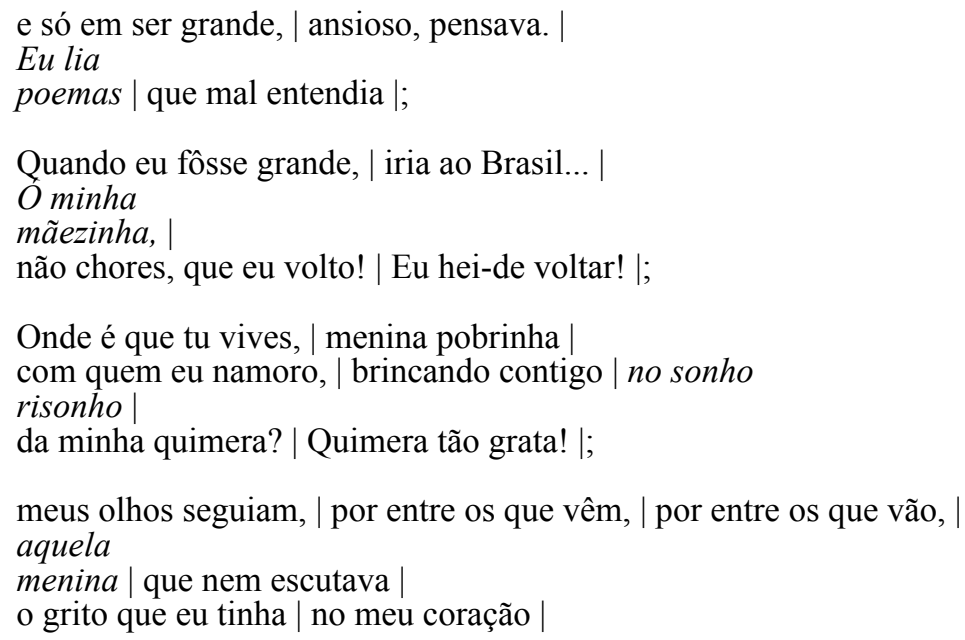

As barras de cadência separam as formas rítmicas pentassilábicas que constituem a base rítmica da poesia. A desarticulação de algumas dessas formas processa-se segundo a modalidade seguinte: o poeta cinde, cada uma delas, em dois elementos dissilábicos, 2(1)+2(1):

\footnotetext{
${ }^{28} \mathrm{~A}$ respeito das longas expressões verbais poéticas (lanços de mais de 12 sílabas métricas) com pretensão a versos simples, e de certos versos compostos muito longos, é útil ler as pertinentes análises desenvolvidas por Amorim de Carvalho in T. g. d. v., vol. I, n. ${ }^{\text {os }} 24,25,34$.

${ }^{29}$ Desarticulação : esta expressão relacionada com o verso e outras expressões equivalentes, são muito do agrado dos modernistas; mas, como estes, em geral, não têm preparação filosófica nem, portanto, estética, e, consequentemente, ignoram, tudo ou quase tudo que é do domínio particular da ciência métrica, - aquela expressão e outras equivalentes são por eles utilizadas com absoluta vacuidade...

${ }^{30}$ Cf. T. g. d. v., vol. I, n. ${ }^{\circ} 54 \mathrm{c} 1,3$.
} 
Eu lia

poemas...;

Ó minha

mãezinha;

... no sonho

risonho;

aquela

menina...

Na realidade, duas possibilidades se oferecem para a boa leitura destes diversos elementos versíficos.

Numa delas, podemos considerar que o poeta quis (por diversas razões que se explicarão à frente) claramente introduzir na poesia o verso quebrado do pentassílabo $5^{2}$ : «Um verso [ou ritmo] diz-se quebrado de outro quando aquele corresponde a um fragmento deste (verso [ou ritmo] inteiro) medido até à sílaba de um acento rítmico principal, se o verso inteiro só tem um acento rítmico, decalcando-o até ao último acento rítmico, se o verso inteiro tem mais do que um acento rítmico. $\mathrm{O}$ verso quebrado vale, assim, como um ritmo suspenso ou incompleto ${ }^{31}$. O quebrado do $5^{2}$ (cuja fórmula numérica analítica é $<2+3>$ ) tem, pois, 2 sílabas métricas, porque o verso $5^{2}$ só possui um acento rítmico principal, que incide sobre a $2{ }^{\mathrm{a}}$ sílaba. Ora, conforme a canónica das combinações heterométricas, os ritmos líricos «combinam satisfatoriamente com os seus respectivos quebrados e fragmentos iniciais» (no caso do $5^{2}$, quebrado e fragmento inicial coincidem). Estamos, portanto, nesta maneira de ver, em presença de verdadeiros versos com autonomia rítmica. $\mathrm{O}$ que nos leva a dizer (na nossa terminologia relacionada com a de Amorim de Carvalho) que certos elementos versíficos:

Eu lia;

Ó minha;

mãezinha;

${ }^{31}$ Definição de verso quebrado e conceitos conexos de fragmento inicial e fragmento terminal: $T$. g. d. v., vol. I, n. ${ }^{\circ} 23$. 
risonho;

aquela;

são versos simples, dissilábicos, quebrados do ritmo pentassilábico de acentuação par, $5^{2}$; e que certos outros:

poemas $\mid$ que mal entendia; com quem eu namoro, | brincando contigo | no sonho; menina | que nem escutava;

traduzem-se em versos compostos irregulares de base pentassilábica: sendo o $1 .^{\circ}$ e o $3 .^{\circ}$, dímetros, pentassílabos de acentuação par articulados com os seus quebrados antepostos; e o $2 .^{\circ}$, trímetro, bipentassílabo de acentuação par articulado com o mesmo quebrado posposto. Como se viu - insistimos - esta disposição métrica não é arbitrária, pois o ritmo pentassilábico de acentuação par combina «satisfatoriamente» com o seu quebrado, conforme indica a canónica das combinações heterométricas fundamentada nas «relações matemáticas parciais» ${ }^{32}: 5^{2}$, desdobrado em $<2+3>$, relaciona-se com o quebrado 2 .

Ora, a desarticulação do pentassílabo $5^{2}$ foi motivada por uma determinação rimática (que o poeta quis valorizar), assim chamada porque ele, optando por pôr em evidência a rima, colocoua no final dos versos (dos versos simples: caso dos dissílabos quebrados do $5^{2}$, e caso dos pentassílabos $5^{2}$; e dos versos compostos). Por outras palavras: os versos «foram determinados por uma partição convencional pela rima $\rangle^{33},-$ sem que o poeta tenha destruído (como se viu) o bom equilíbrio rítmico da poesia. Nesta perspectiva, a leitura da composição poética deverá respeitar as formas rítmicas dissilábicas da escolha do poeta, isto é, deverá ter em conta a existência dos versos quebrados do $5^{2}$, cuja leitura - repetimos - conformar-se-á àqueles critérios de dicção que já atrás evocámos e que pretendemos retomar, também aqui, nas mesmas modalidades gráficas:

\footnotetext{
$\overline{32}$ Vid. na T. g. d. v., vol. I, no importantíssimo cap. IX («As leis das relações matemáticas»), o n. ${ }^{\circ} 61 \mathrm{~b}$.

${ }^{33}$ Versos de determinação rimática : Vid. T. g. d. v., vol. I, n.os 54c (para este caso específico), 89 (em geral).
} 
Eu lia $\|$

poemas | que mal entendia; ||

Ó minha $\|$

mãezinha $\|$

com quem eu namoro, | brincando contigo | no sonho ||

risonho \||

Às vezes, à hora | em que eu, da janela, || as ruas olhava, || meus olhos seguiam, | por entre os que vêm, | por entre os que vão, || aquela $\|$

menina $\mid$ que nem escutava $\|$

o grito que eu tinha | no meu coração, ||

chamando por ela... $\|$

O poeta faz sobressair a rima; a rima, aqui, determina a forma do verso. Se nas primeiras três transcrições acima, o verso quebrado participa do sistema de rimas emparelhadas, já na última, a palavra «aquela», na sua preeminência rítmica dissilábica, autónoma, tem, por sua situação intermédia, a função de não deixar ficar inoperante, não deixar morrer para o ouvido a rima muito remota de «janela» e «ela» ${ }^{34}$. E tanto mais remota que a distância objectiva entre essas duas palavras rimadas, já de si importante (se excluirmos a expressão «aquela» que vai precisamente, servir de elo de ligação rimática), torna-se desmesuradamente alongada numa extensíssima distância subjectiva, pela inserção, entre «janela» e «ela», de 5 formas versíficas que compreendem 1 verso simples +3 versos compostos +1 verso simples representando 9 períodos rítmicos (4 formas rítmicas pentassilábicas +1 dissilábica +4 pentassilábicas). Porque, se «os versos têm

\footnotetext{
${ }^{34}$ Neste estudo sobre ritmo não abordaremos a função da rima, a sua influência estética, as sugestões que empresta à poesia. Podíamos abordá-las. A rima sublinhará, as mais das vezes, o ritmo da composição poética. Amorim de Carvalho redigiu, no vol. I da $T$. g. d. v., uma extensa análise sobre a rima (n. ${ }^{\text {ss }} 80$ a 94 ), incluindo algumas observações a respeito da ausência de rima em poesias de ritmo pentassilábico (n. ${ }^{\circ}$ 94a). Rimas emparelhada e remota: $T$. g. d. v., vol. I, n. ${ }^{\circ} 87 \mathrm{~b}, \mathrm{f}$. Como repetição que é, a rima será considerada uma forma de ritmo - um ritmo efectivo (janela-aquela-ela). Cf. as interessantíssimas considerações de Amorim de Carvalho a respeito do «ritmo sonoro» ou «auditivo» e do «ritmo plástico», onde o conceito de ritmo está generalizado como forma de interpretação de certos aspectos do conhecimento estético: $T$. $g$. $d$. v., vol. I, n. ${ }^{\circ} 11 \mathrm{~d}$.
} 
uma duração objectiva que resulta da extensão métrica [...], da natureza das sílabas, dos acentos internos [...]», dessa «duração objectiva depende a distância objectiva entre o final de um verso e o final [...] [de outro verso]. Mas há uma distância subjectiva que [...] depende [...] do número de períodos rítmicos [sublinhamos nós] [...]», que «pertence à pura sensibilidade auditiva $[\ldots] \gg{ }^{35}$. É, pois, para atenuar essa distância subjectiva entre palavras rimadas que o poeta, muito subtilmente, introduziu o verso quebrado «aquela» em situação que valorizasse a rima, preservando no entanto a boa combinação rítmica, como já vimos.

A outra possibilidade de leitura, seria privilegiar a dicção em ritmos pentassilábicos, já então não nitidamente desarticulados na maneira de dizer, abrindo apenas suspensões que evidenciassem a rima (suspensão por imposição rimática ou pedida pela rima), como a seguir se indica:

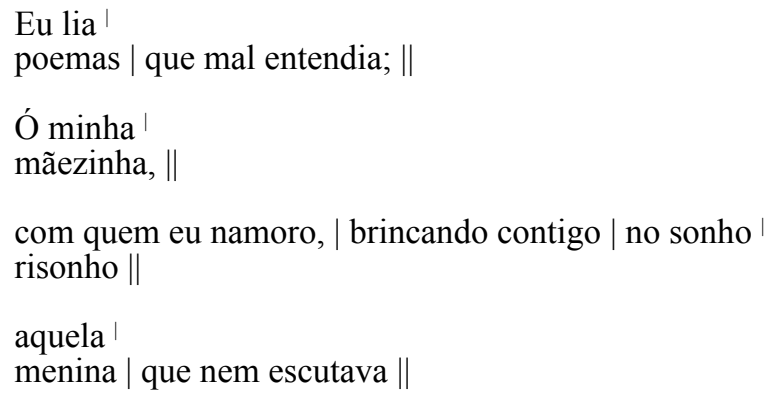

- o que não nos parece estar no propósito do poeta e que empobreceria ritmicamente a poesia.

Para concluir, podemos dizer que a inserção, esparsa e comedida, dos dissílabos, versos quebrados do ritmo pentassilábico de acentuação par, base da expressão rítmica da poesia, - contribui, também, com a intermeação das formas pentassilábicas simples e compostas, para imprimir à «Balada» uma leveza melódica que rompe, agradavelmente, com certa rigidez repetitiva, embora muito cantante, do ritmo pentassilábico.

$\overline{{ }^{35} T . g} . d$. v., vol. I, n. ${ }^{\circ} 24 \mathrm{c}$. 
Chegamos ao término do minucioso estudo métrico da «Balada do menino» - uma das duas poesias de ritmo pentassilábico incluídas no livro Verbo doloroso. Passaremos agora ao exame atento da outra poesia - «Pela noite» - também composta na forma pentassilábica, mas à qual Amorim de Carvalho, dando a acentuação ímpar, imprimiu uma bem diferente característica rítmica. Porque, enquanto o ritmo pentassilábico de acentuação par, no dizer rápido e abarcante de Amorim, «é duma toada doce e lenta», expressando "suave languidez», a acentuação ímpar dá-lhe um «andamento musical [...] mais apressado e vivo e até gárrulo no seu ritmo breve» ${ }^{36}$. À diferença do outro, o pentassílabo de acentuação ímpar encerra maior leque de possibilidades rítmicas porque, opostamente à acentuação, sempre a mesma, na 2. ${ }^{a}$ sílaba do pentassílabo de acentuação par, - o de acentuação ímpar comporta diversas nuanças acentuais, isto é: pode receber acentuação principal ora na $1 .{ }^{\mathrm{a}}$ sílaba, ora na $3 .{ }^{\mathrm{a}}$, mas ainda, cumulativamente, nessas duas sílabas. Esta maior diversidade rítmica se expressará, na fórmula sintética de notação numérica, por: $5^{1-13-3}$ (a ordem dos expoentes é arbitrária), e, na fórmula analítica, por: $<1+4>,<1+2+2>$ ou $<3+2>$. Em «Pela noite», o poeta utilizou, pois, este ritmo nas formas, como veremos, simples e compostas (salvo uma excepção, que também estudaremos adiante).

Os elementos versíficos desta bela poesia estão distribuídos por 7 parástrofes, sendo que, nas 4 primeiras - as mais extensas -, o poeta interpela, alternadamente, a sua Amada e o mendigo desconhecido que passa, cantando, no ermo da noite; nas 3 seguintes, muito curtas ( 2 das quais formadas por um único verso composto), o poeta, exausto, exprime, «com temor e pena», o desejo de descanso para a sua alma, mas não pode deixar de lembrar a misteriosa voz que, lá fora, chora, a «voz que pede».

Das formas pentassilábicas de acentuação ímpar desta poesia, apenas 8 são simples, tomando quase todas as outras a estrutura composta bipentassilábica e tripentassilábica (a exemplo da «Balada» anteriormente estudada). Em «Pela noite» surge, entretanto, a novidade do quadripentassílabo que abre a poesia:

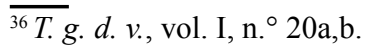


Minha Amada, ouves? Uma voz ergueu-se, a cantar, na noite. É algum cèguinho

Põe-se aí a questão, atrás evocada, da incapacidade, para o ouvido, de apreender, agradavelmente, como tais, ritmos extensíssimos. Amorim de Carvalho, notável ritmista e teorizador da Versificação, não podia deixar de ter consciência desta limitação. Estudando os «pentadecassílabos» do poeta brasileiro Carlos Magalhães Azeredo, ele os considera não fixáveis «pelo ouvido, como um todo rítmico simples»; e acrescenta que os «pentadecassílabos» «não se desdobram como versos compostos que o ouvido retenha com agrado, quando tal desdobramento se poderia fazer. Isto prejudica a beleza do tema, fatigando o ouvido ${ }^{37}$. A respeito dum verso composto de ritmo recitativo - o tetrâmetro quadritetrassilábico -, Amorim de Carvalho escreve: «[...] cada um destes quadritetrassílabos vale como dois bitetrassílabos [...] e a dicção se faz com agrado deste modo, como dois versos $[\ldots]\rangle^{38}$. Perante isto, como considerou, então, o poeta, a forma quadripentassilábica acima transcrita? Certamente como dois versos: um tripentassílabo e um pentassílabo, separados, aliás, claramente, por pausa indicada pelo ponto final:

Minha Amada, ouves? | Uma voz ergueu-se, | a cantar, na noite.

\|É algum cèguinho $\|^{39}$

Podemos admitir - perguntamos - que certas formas bipentassilábicas e tripentassilábicas sejam cindidas em ritmos mais reduzidos, - dada a existência de separações lógicas, explicitamente indicadas pela pontuação final de diversos componentes?:

Minha Amada ouves? || Uma voz ergueu-se, | a cantar na noite.

Minha Amada ouves? || Encostado à porta; || É algum cèguinho;

- Deixa-me dormir! || Como o vento é triste! || Como ruge o mar!...;

Ouves? Canta sempre.|| Canta a soluçar, | junto das janelas...;

Segue. Toda a alma | tem o seu destino. || Qual será o teu?;

$\overline{{ }^{37} T .}$ g. d. v., vol. I, n. ${ }^{\circ} 24 \mathrm{a}$.

${ }^{38}$ T. g. d. v., vol. I, n. ${ }^{\circ} 34$.

${ }^{39}$ Indicamos, como de hábito, a suspensão, ou o «descaímento» final do verso, pela dupla barra de cadência ( $\|$ ). 
Minha Amada, ouves? || Vai-se a voz sumindo, | trémula e distante...;

Cubro mais meu corpo, | com temor e pena... || Já se foi embora?

Mas tal modo de dizer, redundaria na destruição de quase todas as formas tripentassilábicas, o que rejeitamos; estas formas são uma das modalidades rítmicas que o poeta vem adotando, na sua poesia, com perfeita consciência técnica.

Há, no entanto, dois casos nos versos acima transcritos, que queremos particularmente analisar. $\mathrm{O}$ terceiro e o quarto tripentassílabos têm, nos primeiros componentes, cortes rítmicos respectivamente entre Ouves? e Canta, e entre Segue. e Toda. Corte rítmico é «uma pausa lógica que parece interceptar o todo musical do verso» ou ritmo ${ }^{40}$ :

Ouves? Canta sempre. |...;

Segue. Toda a alma $\mid \ldots$

Essa leve intercepção no ritmo, ou pausa brevíssima, ou curta suspensão, não deverá, pois, perturbar a harmonia rítmica, «o todo musical do verso». Mas note-se que o poeta levou a perfeição técnica até colocar o corte rítmico, precisamente na posição em que o pentassílabo se reparte em dois elementos de 1 e 3 sílabas (quebrados ou fragmento inicial ${ }^{41}$ ) com os quais se «combinam satisfatoriamente» os ritmos pentassilábicos de acentuação ímpar ${ }^{42}$, acentuados, como sabemos, na $1 .^{\mathrm{a}}$, na 3 . $^{\mathrm{a}}$ ou na $1 .^{a}$ e $3 .^{a}$ sílabas. Aquele requinte técnico terá, sem dúvida, o objectivo de reduzir, por mais leve que ela seja, a perturbação

$\overline{{ }^{40} T .}$ g. d. v., vol. I, n. ${ }^{\circ} 5$ b.

${ }^{41} \mathrm{O}$ conceito de quebrado está definido atrás. Fragmento inicial é o «primeiro grupo silábico apoiado no $1 .^{\circ}$ acento rítmico principal, se o verso tem mais do que um acento rítmico; se tem um só acento rítmico, [...] fragmento inicial e quebrado se confundem» (T. g. $d$. v., vol. I, 23c), - donde resulta que, no pentassílabo de acentuação ímpar, o fragmento inicial tem 1 sílaba no $5^{13} \mathrm{e}$, nos pentassílaos $5^{1}$ e $5^{3}$, os fragmentos iniciais coincidem com o quebrado.

${ }^{42}$ T. g. d. v., vol. I, n. ${ }^{\circ} 63$ («Canónica das combinações heterométricas»). - O relacionamento dos quebrados, fragmentos iniciais e fragmentos terminais com os respectivos ritmos inteiros, exige uma técnica muito subtil cujos princípios, formulados por Amorim de Carvalho, são bastante complexos (Vid. T. g. d. v., vol. I, n. $\left.{ }^{\circ} 23\right)$. - Não só a teoria mas ainda a terminologia deste interessante aspecto do ritmo verbal, têm também suas origens nas obras de Amorim de Carvalho sobre Versificação. 
que o corte rítmico poderia originar, - restabelecendo, por nova via, uma harmonia rítmica satisfatória.

$\mathrm{Na}$ última parástrofe da poesia agora estudada, Amorim de Carvalho retoma o processo de desarticulação do ritmo pentassilábico em elementos versíficos de determinação rimática; mas enquanto que na «Balada do menino» ele o utilizara em quatro momentos, em «Pela noite» emprega-o uma única vez, no belo fecho da poesia:

Prende-me ao teu seio, | minha Bem Amada... ||

A minh'alma ao sono, | fatigada, || cede... $\|$

Mas com mais tristeza | no meu sonho, agora, || ouço a voz que chora, $\|$

ouço a voz que pede...

O poeta cinde o ritmo pentassilábico de acentuação ímpar $5^{1-}$ 13-3 em seus quebrados ou fragmento inicial: «fatigada» (3 sílabas métricas), «cede» (1 sílaba métrica), - e fá-lo com a intenção de valorizar a rima, propósito este que já fôra o dele nos casos similares da «Balada do menino» (que longamente, atrás, estudámos). A diferença está apenas - mas esta diferença é ritmicamente determinante - no número de sílabas métricas dos quebrados e fragmento inicial: se na «Balada» quebrado e fragmento inicial do $5^{2}$ coincidem e não podem deixar de ter 2 sílabas métricas, em «Pela noite», poesia composta em $5^{1-13-3}$, os quebrados e fragmento inicial são de 3 ou 1 sílabas métricas, pois só estas «combinam satisfatoriamente» com o pentassílabo de acentuação ímpar.

Pois bem. A boa colocação dos quebrados e fragmentos iniciais numa composição pentassilábica com acentuação ímpar, parece exigir curta distância subjectiva ${ }^{43}$ entre eles e os inteiros que condicionam a acentuação daqueles quebrados e fragmentos iniciais; isto é, para que a toada se mantenha, agradàvelmente, no ouvido, impor-se-á certa aproximação subjectiva entre uns e outros. Cremos que esta exigência provém do facto da acentuação no pentassílabo $5^{1-13-3}$, ser não incerta, como no ritmo

\footnotetext{
${ }^{43}$ Como indicámos atrás, o conceito de distância subjectiva se encontra explicado na T. g. d. v., vol. I, n. ${ }^{\circ} 24 \mathrm{c}$.
} 
heptassilábico, mas variável. Em:

A minh'alma ao sono, | fatigada, || $5^{3} \mid 3$

cede... $\| 1$

Mas com mais tristeza | no meu sonho, agora, $\| 5^{1-3} \mid 5^{3}$

$o u c ̧ o$ a $v o z$ que chora, $\| 5^{1-3}$

$o u c ̧ o$ a $v o z$ que pede... $5^{1-3}$

nós interpretamos o monossílabo métrico «cede» como fragmento inicial e propomos, consequentemente, fazer pausa de compensação a seguir a Mas (substituindo, assim, nessa 1. ${ }^{\mathrm{a}}$ sílaba, a tónica que lhe falta) ${ }^{44}$, - compensação essa solicitada pelo dito fragmento inicial, de modo a diminuir a distância subjectiva entre este fragmento e um verso acentuado na $1 .{ }^{a}$ sílaba:

Mas ${ }^{\mid}$com mais tristeza $\mid \ldots$

Esta subtilidade técnica vem apenas sustentar ou reforçar uma relação já próxima existente entre esse fragmento inicial (cede) e as precedentes e as posteriores acentuações nas 1. ${ }^{\text {as }}$ sílabas (ver, atrás, as respectivas transcrições completas):

Prende-me... $\mid$ minha...

$$
\begin{aligned}
& \text { cede... } \\
& \text { Mas |... } \\
& \text { ouço... } \\
& \text { ouço... }
\end{aligned}
$$

Estaria na intenção do poeta, propor, simplesmente, uma dicção pentassilábica, apesar da desarticulação gráfica do pentassílabo?:

... | fatigada, cede... II

Não cremos: também aqui - como para a poesia anteriormente estudada -, não aceitamos nem preferimos essa possibilidade. A leitura deverá respeitar esse «ritmo suspenso ou incompleto»

$\overline{{ }^{44} T .}$ g. d. v., vol. I, n. ${ }^{\circ} 20 \mathrm{e}$. 
do quebrado ${ }^{45}$, depois, o do fragmento inicial:

... fatigada, ||
cede... ||

os quais, no fechar da poesia, reforçam, pela conceptualização da forma, a ideia dos derradeiros versos, numa bela harmonia expressiva ${ }^{46}$ : o poeta, esgotado, deixa-se levar para o sonho duma realidade como que suspensa no devaneio de longínqua lembrança.

Por algumas das considerações que acabamos de tecer à volta dos quebrados e fragmentos iniciais dos versos pentassilábicos de acentuação ímpar, o leitor atento se aperceberá, sem dúvida, que consideramos ter, neste domínio do conhecimento rítmico, atingido os limites do que nos é legitimamente permitido racionalizar; somos consciente das dificuldades encontradas, nesse esfôrço mesmo de racionalização, ao confrontarmo-nos, aqui, com situações que já estão na origem de certa indeterminação do ritmo verbal; essas hesitações, experimentou-as também o insigne poeta e teorizador da Versificação que foi Amorim de Carvalho, ao manifestar, na redacção de alguns parágrafos, na $T$. g. $d$. v., sobre versos compostos irregulares ${ }^{47}$, a sua perplexidade: «Parece-nos - a concluir das nossas experiências pessoais - ...», «Não nos parece...», etc. ${ }^{48}$.

A acentuação rítmica - para uma boa técnica versificatória - deve ser, como vimos, inequívoca: o princípio é válido para todos os ritmos. Na poesia aqui analisada, composta com 73 ele-

$\overline{{ }^{45} T .}$ g. d. v., vol. I, n. ${ }^{\circ} 23 \mathrm{a}:$ : $\mathrm{O}$ verso quebrado vale [...] como um ritmo suspenso ou incompleto», já o referímos atrás.

${ }^{46}$ A «harmonia expressiva é uma conceptualização da forma - fenómeno estético pelo qual a forma, isso que o verso é como forma sonora verbal, toma uma certa e imediata significação, identificando-se com o sentido das palavras, ou, se se quer, o sentido das palavras identificando-se com a forma». Quando a harmonia expressiva «traduz coisas do mundo físico, movimentos, acções, etc., pelos próprios sons das palavras ditas onomatópicas», Amorim de Carvalho chama-a harmonia imitativa ou onomatopeia. Esta é pois um aspecto da harmonia expressiva, que é um caso da conceptualização da forma (T. g. d. v., vol. I, n. $\left.{ }^{\circ} 77\right)$.

${ }^{47}$ Vol. I, n. ${ }^{\text {s }} 53 \mathrm{~b}$ in fine, $54 \mathrm{c} 3$.

${ }^{48}$ Vid., tb., T. g. d. v., vol. I, n. ${ }^{\circ} 61 \mathrm{~b}:$ «[...] mas estas boas relações matemáticas parciais já são de mais difícil classificação [...] e de mais delicada realização [...]». 
mentos rítmicos pentassilábicos de acentuação ímpar, só em três situações podemos encontrar acentos próprios ou naturais, em sílabas pares, mais fortes que os das sílabas ímpares que se lhes justapõem:

Quem és tu que pedes, ...;

se $n \tilde{a} o$ temos nada,...;

... que não sei quem és!...-

Porém, as sílabas quem, tu, te (de temos) e sei, possuem certa tonicidade própria ou natural. Noutro caso, o acento na 2. ${ }^{a}$ sílaba é de valor mais ou menos equivalente ao da 3. ${ }^{\mathrm{a}}$ (têm):

... que não têm estrelas...

Ora, pela sua colocação em posições rítmicas aliada à tonicidade própria, as sílabas quem, tu, te (de temos), sei e têm, adquirem notável «valor de acento rítmico» a ponto de exercerem (as últimas quatro) uma atracção proclítica sobre as sílabas que se lhes antepõem $(\dot{e} s \rightarrow t u, n \tilde{a} o \rightarrow$ temos, $n \tilde{a} o \rightarrow s e i, n \tilde{a} o \rightarrow t e ̂ m)$. Tudo concorre, efectivamente, para o refôrço da tonicidade das $1 .^{\mathrm{a}} \mathrm{e}$

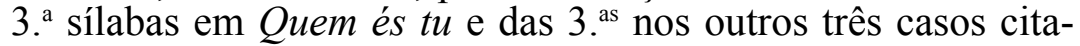
dos: é que a «simples fôrça posicional rítmica chega a fazer-se valer por si só» ${ }^{49}$, fenómeno que está na origem da lei da tonicidade posicional, já referida ${ }^{50}$; e as situações explicadas pela lei da subordinação ou assimilação rítmic ${ }^{51}$ mais confortam a tonicidade própria ou natural (embora fraca) das $1 .{ }^{\text {as }}$ e $3 .^{\text {as }}$ sílabas relativamente à das $2 .^{\text {as }}$.

Nas circunstâncias seguintes:

Mas não há migalhas...;

...já não dá calor... -;

Ficou só na treva

reconhece-se que as $2 .^{\text {as }}$ sílabas - não, cou (de Ficou) - têm

$\overline{{ }^{49} T . g}$. d. v., vol. I, n. ${ }^{\circ} 21 \mathrm{c}$.

${ }^{50}$ T. g. d. v., vol. I, n. ${ }^{\circ} 21 \mathrm{e}$.

${ }^{51}$ T. g. $d$. v., vol. I, n. ${ }^{\circ} 68$. Transcrevêmos in extenso esta lei na nota ${ }^{26}$ do nosso anterior estudo publicado na «Rhythmica», n. ${ }^{\circ}$ 3-4 (2006). 
inegável tonicidade própria; mas totalmente dominadas que estão pelas fortes tonicidades próprias da $1 .{ }^{\mathrm{a}} \mathrm{e} 3{ }^{\mathrm{as}}$ ( $\left.h a ́, j a ́, d a ́, ~ s o ́\right)$, a dicção espontânea nem releva os acentos dominados daquelas 2 as $^{\text {as }}$ ílabas.

Insistir nestes pontos, numa perspectiva crítica, como vimos fazendo há momentos, é, sem dúvida, severidade exagerada, e talvez mesmo descabida. Na poesia presentemente estudada, pode-se considerar que a inequivocidade da acentuação é, pràticamente, absoluta.

Porque o pentassílabo de acentuação ímpar pode ter unicamente acentuação rítmica na 1. ${ }^{a}$ sílaba, ele - diz Amorim - «se presta ao emprego de palavras esdrúxulas, com interessante efeito estético ${ }^{52}$. Ora este poeta apenas utilizou esse processo em:

Trágico de fome,...;

... lôbrego talvez...;

... trémula e distante...

evitando todo o exagêro, não se deixando levar por essa facilidade rítmica; essas formas foram, aliás, unicamente utilizadas em versos longos (dois tripentassílabos e um bipentassílabo). No entanto, a acentuação única na 1 . $^{\mathrm{a}}$ sílaba sem esdruxulação surge algumas vezes:

... pela madrugada;

... pôr-te no caminho;

canta a soluçar!;

- Deixa-me dormir!;

nada que te dar?;

... canta a soluçar, | junto das janelas...;

... enches-me de medo;

como as ventanias $\mid$ dentro do arvoredo;

Vens esfarrapado...;

... cheias de traições!;

inda suplicante...;

Em:

... Já se foi embora?;

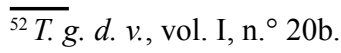


Prende-me ao teu seio, | minha Bem Amada...

como a tonicidade própria forte da 1 . $^{\mathrm{a}}$ sílaba dos componentes pentassilábicos ocupa um dos lugares do acento rítmico, - «a tonicidade fraca no outro lugar $[f o i, m e a o, B e m]$ não conta senão como acento rítmico secundário, e para uma análise menos minuciosa nem será contada como acento rítmico secundário ${ }^{53}$. A acentuação única na 1 . $^{\mathrm{a}}$ sílaba, $5^{1}$, impõe um como que alongamento da frase, atenuando, assim, a vivacidade natural deste ritmo de acentuação ímpar. Esse desenho melódico vem, sem dúvida, enriquecer a toada própria do pentassílabo.

Ao concluirmos a análise rítmica da poesia «Pela noite», queremos fazer referência, mais especialmente agora, à heterometria nela utilizada por Amorim de Carvalho. Para uma melhor compreensão do processo, passamos a transcrever:

Minha Amada, ouves? Uma voz ergueu-se, a cantar, na noite. É algum cèguinho

que perdeu a estrada,

e ficou sòzinho...

- Ó cèguinho, espera!, que ao romper do Sol, pela madrugada, nós contigo iremos pôr-te no caminho! -

Minha Amada, ouves? Encostado à porta canta a soluçar!

- Deixa-me dormir! Como o vento é triste! Como ruge o mar!...

Quem és tu que pedes, pela noite morta, se não temos nada, nada que te dar?

Trágico de fome, a tremer de frio, que cruel horror!, andas, com certeza.

Mas não há migalhas sobre a nossa mesa, e a braseira, extinta, já não dá calor...-

Ouves? Canta sempre. Canta a soluçar, junto das janelas...

- Pobrezinho triste, enches-me de mêdo, como as ventanias dentro do arvoredo nas escuras noites que não têm estrelas... Que é que tu me queres, que paraste aqui?

Segue. Toda a alma tem o seu destino. Qual será o teu?

Tu me fazes pena, quando penso em ti...

Tu me fazes susto, quando fito o céu...

$\overline{{ }^{53} T . g . d .}$., vol. I, n. ${ }^{\circ} 20 \mathrm{c}$ in fine. 
Sobre ti caíram chuvas e tufões...

Vens esfarrapado, lôbrego, talvez...

$\mathrm{Ai}$, mas são as noites cheias de traições!

Segue o teu caminho, que não sei quem és!... -

Minha Amada, ouves? Vai-se a voz sumindo, trémula e distante...

Ficou só na treva

um anseio mudo que no ar se eleva,

inda suplicante...

Cubro mais meu corpo, com temor e pena... Já se foi embora?

Prende-me ao teu seio, minha Bem Amada...

A minh'alma ao sono, fatigada,

cede...

Mas com mais tristeza no meu sonho, agora, ouço a voz que chora,

ouço a voz que pede...

A heterometria é determinada por dois factores: um, rimático; o outro, rítmico. O poeta, querendo valorizar a rima, dispõe os versos por determinação rimática; mas, concomitantemente, constrói-os dentro de uma certa diversidade rítmica (são os compostos pentassilábicos, de heterometria, portanto, regular, escritos com a consciência técnica que se lhe conhece, inclusive naquele caso único que faz excepção, como atrás se viu). Assim, vai Amorim imprimindo à poesia as mudanças rítmicas espontaneamente contidas naqueles compostos que naturalmente participam do ritmo simples pentassilábico de acentuação ímpar, também, como tal, utilizado, nesta poesia.

Como fizemos notar no estudo sobre a «Balada do menino», Amorim de Carvalho não se preocupou, no Verbo doloroso, em introduzir, sistemàticamente, nos compostos líricos, cesuras átonas $^{54}$. Já vimos que o ritmo pentassilábico, que é forte, obsta naturalmente à elisão: opõe-se-lhe a diálise rítmica que é pedida espontaneamente por este ritmo, como demoradamente se explicou atrás. Donde, versos compostos como estes (similares aos da

\footnotetext{
${ }^{54}$ No livro Destino, Amorim de Carvalho dera sistemàticamente cesura átona aos bipentassílabos. Vid. nosso estudo in «Rhythmica», n. ${ }^{\circ}$ 3-4 (2006), págs. 25-27. Cf. T. g. d. v., vol. I, n. ${ }^{\circ}$ 30c.
} 
«Balada», também de base pentassilábica, embora de acentuação par):

... que ao romper do Sol, pela madrugada;

Trágico de fome, a tremer de frio...

nos quais se verifica a tendência, que conhecemos, neste ritmo forte que é o pentassilábico, para o prolongamento paragógico (Sole) ou para a suspensão de tempo vazio (Sol|...) ou para o hiato rítmico, impedindo a sinalefa (entre me, de fome, e $a$ ), a marcar a diálise rítmica, que resulta da franca propensão separativa que se opõe à elisão rítmica.

\section{*}

Essa heterometria na obra de Amorim de Carvalho, de que temos vindo a tratar, - levou-a o poeta a expoentes únicos na literatura de expressão portuguesa, com desenvolvimentos absolutamente originais, muito belos e complexos realizados, com perfeita consciência técnica, em poesias e poemas sobretudo de ritmo recitativo. Tal aspecto da criação poética amoriniana está já bem representado nos livros Destino e Verbo doloroso. Esperamos tratar, noutra ocasião, desta perturbante feição da obra poética de Amorim de Carvalho.

Mas por agora, e sempre sem sairmos da modalidade lírica, vamos abordar unicamente as composições que, incluídas ainda em Verbo doloroso, foram realizadas em ritmo heptassilábico - no qual, aliás, Amorim de Carvalho jamais praticou a heterometria.

Foram sete, como vimos, as poesias que, nesse ritmo, o poeta incluiu no livro Verbo doloroso. Cinco, em heptassílabos. Duas em bieptassílabos; uma destas, em língua castelhana, com dedicatória à poetisa argentina Paulina Simoniello.

As poesias compostas em versos simples heptassilábicos, repartem-se em dois tipos, do ponto de vista estrófico: duas, estão organizadas dentro de modalidades estróficas pròpriamente ditas, isto é, como tais admitidas tradicionalmente ${ }^{55}$ :

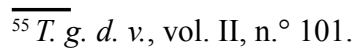


a quadra ${ }^{56}$ («Cigana») e a décima ${ }^{57}$ («Esperar»); as outras três («Ausência e amor», «O mistério da vida» e «A filha do sineiro»), desenvolvem-se em parástrofes mais ou menos longas, cada uma destas correspondendo - pela própria definição de parástrofe, que já conhecemos - a uma real unidade de assunto.

Situação há em que, por exemplo, uma aparente estrofe (que seria uma quadra) não o é realmente, pois não tem unidade rimática, transportando-se a rima de uma parástrofe a outra; é o caso do fecho da poesia «Ausência e amor»:

E o antigo amor sem amor foi na ausência que se fez; nasceu depois que a deixei: era um botão - fez-se a flor.

Amava-a já desta vez, mas foi já tarde que a amei...
A
B
C
A

B

$\mathrm{C}$

Na realidade, o poeta escreveu dois parágrafos poéticos, no entanto não arbitrários porque cada um deles possui unidade de pensamento - aos quais, nestes casos, como se sabe, chamamos parástrofes; uma destas tomou a forma aparente da quadra. Se no «Mistério da vida» há unidade rimática em cada uma das extensas parástrofes que terminam, todas, num refrão:

Da primeira parástrofe:

Tudo é pó, tudo ilusão.

Fica um silêncio que gela, porque dentro do caixão vai para a campa florida a terrível coisa bela que é a vida.

Da nona e última:

Para o coração que chora

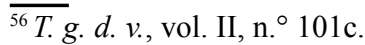

${ }^{57}$ T. g. d. v., vol. II, n. ${ }^{\circ} 101 \mathrm{i}$. 
nunca mais haverá calma?...

Não soará, nunca, a hora

tão desejada e temida,

em que me tirem da alma

- que eu não posso mais com ela -

a terrível coisa bela

que é a vida?...

já na «Filha do sineiro» não existe essa unidade:

Das duas primeiras parástrofes:

vibra no bronze do sino

a primeira badalada.

Primeira nota dum hino que a notícia ao mundo leva

na sua voz magoada!

E dentro de pouco aos céus um poema de dor se eleva, em apêlo erguido a Deus.

Das terceira e quarta:

triste olhando para o céu, pergunta cheio de dor:

-Quem seria que morreu?...

E o solitário pastor,

Das sexta e sétima (fecho da poesia):

...Último clamor funéreo

caindo num cemitério, onde um caixão enfeitado desce ao leito derradeiro... enquanto o povo assombrado pergunta o que sucedeu... 
Nada. Só foi o sineiro

que de dor enlouqueceu...

Nas 6 quadras de «Cigana», o poeta adoptou sistemàticamente a travação rimática clássica: ABBA, etc. (rima interpolada ${ }^{58}$ ). $\mathrm{Na}$ poesia «Esperar», cada uma das 3 primeiras décimas foi construída com esquemas rimáticos e de pensamento que dão às estrofes formas compostas $(1$ sextilha +1 quadra separadas uma da outra por pausa lógica no final do $6 .^{\circ}$ verso, tendo cada um dos componentes «seu pensamento próprio e suas rimas próprias»). Porém, na 4. ${ }^{a}$ e última décima, a pausa lógica passa para o final do $5 .^{\circ}$ verso, o que tira à décima a forma composta sextilha + quadra, embora o esquema rimático se mantenha como nas precedentes estrofes:

\section{1. ${ }^{a}$ décima:}

Pairava um grande tormento A nesse caminho sombrio, B passagem de extinto rio $\quad$ B que causava um arrepio, B lembrando um rasto de frio B deixado ali pelo vento. A Numa ansiedade sincera, $\quad$ C achei-me triste e sòzinho, D no meio desse caminho D e ali me fiquei à espera. $\quad \mathrm{C}$

\section{4. décima:}

Ave que busca onde acoite a vida que vai findar, pálpebras que vão fechar sôbre o derradeiro olhar - caiu o Sol sôbre o mar... Passou a Sombra da Noite, M e ao ver o meu vulto austero, no caminho, perguntou

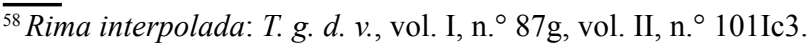


Nesta estrofe, o $6 .^{\circ}$ verso que, rimàticamente, pertence ao grupo dos 6 primeiros versos, pertence também, pela fôrça da pontuação, em lógica, aos 5 últimos versos da décima. Dado que «Nenhum esquema rimático da décima [como estrofe] se consagrou de modo especial» ${ }^{59}$, o poeta propôs uma muito bela travação rimática que não foi apresentada, por ele, na sua $T . g . d$. v.: ABBBBACDDC, EFFFFEGHGH, IJJJJIKLLK, MNNNNMOPOP ${ }^{60}$, onde os últimos quatro versos têm, alternadamente, rimas interpoladas e cruzadas $^{61}$. A rima, embora muito remota, do $1 .^{\circ}$ e $6 .^{\circ}$ versos de cada estrofe, mantém-se sem esfôrço apreciável, na memória auditiva. «A distância das rimas remotas deve ter o limite que o ouvido apreenda», escreve com razão Amorim de Carvalho ${ }^{62}$. Há aqui um fenómeno curioso que pretendemos explicar. Vejamos a seguinte quintilha de Castilho:

Saiu todo o povo, ficaram ali, dançando às escuras em dança hedionda;

veio o novo dia, durava inda a ronda, sem que haja de tantos um só que responda a quem se dói deles, ou deles se $r i$.

Apesar da grande distância objectiva e subjectiva entre o final do $1 .^{\circ}$ verso e o final do $5 .^{\circ}$ verso (há entre eles, respectivamente, 4 bipentassílabos de cesura átona e 8 períodos rítmicos), o «efeito auditivo da rima» parece manter-se aí, mais nítido, mais presente no ouvido do leitor do que o dos dois versos rimados da sextilha heptassilábica do poeta brasileiro Manuel Bandeira, que passamos a transcrever (com uma alteração experimental no $4 .^{\circ}$ verso):

O meu quarto vai ficar, não como forma imperfeita neste mundo de aparências:

\footnotetext{
$\overline{{ }^{59} T .} g . d$. v., vol. II, n. ${ }^{\circ}$ 101Ii3. - Há que distinguir a décima-estrofe da décima-sistema estrófico (que Amorim apelida de «décima clássica ou espinela») que é um «sistema estrófico com número fixo de estrofes e formas estróficas fixas» constituído por 1 quadra +1 sextilha (T. $g . d$. v., vol. II, n. $\left.{ }^{\circ} 110\right)$.

${ }^{60} \mathrm{O}$ tipo de travação rimática da sextilha desta décima-estrofe amoriniana, encontra-se na sextilha de uma décima-sistema estrófico do poeta espanhol Ferrant Manuel de Lando (T. g. d. v., vol. II, n. $\left.{ }^{\circ} 110 \mathrm{a}\right)$.

${ }^{61}$ Rima cruzada: T. g. d. v., vol. I, n. ${ }^{\circ} 87 \mathrm{e}$.

${ }^{62}$ T. g. d. v., vol. I, n. ${ }^{\circ} 87 \mathrm{~g}$.
} 
[ficará] na eternidade, com seus livros, com seus quadros, intacto, suspenso no $a r$ !

os quais também não chegam a atingir a fôrça de valor rimático, a fôrça de permanência auditiva da rima dos $1 .^{\circ}$ e $6 .^{\circ}$ versos das sextilhas (componentes das décimas), igualmente em versos heptassilábicos, da poesia «Esperar» de Amorim de Carvalho, de que demos, atrás, um exemplo que voltamos a transcrever:

Pairava um grande tormento nesse caminho sombrio, passagem de extinto rio que causava um arrepio, lembrando um rasto de frio deixado ali pelo vento. ${ }^{63}$

Como explicar, efectivamente, estes factos? Nós admitimos que o encanto (em-canto) da rima nos versos interpolados (é o caso das estrofes de Castilho e Amorim) ajuda a conservar e a reforçar no ouvido o «efeito auditivo» da rima remota ${ }^{64}$ : o emcantamento rimático vai criando, assim, um hábito de canto, de melopeia, que facilita a retenção da rima remota no espírito do leitor, - e é precisamente isto que não se verifica nos versos interpolados não rimados de Manuel Bandeira na forma que lhes demos. Eis a razão, a nosso ver, pela qual o poeta brasileiro, para salvar a rima externa em ar, introduziu a rima interna ${ }^{65}$ (ficar) no $4 .^{\circ}$ verso:

O meu quarto vai ficar, não como forma imperfeita neste mundo de aparências:

vai ficar na eternidade, com seus livros, com seus quadros, intacto, suspenso no $a r$ !

tentando, deste passo, mas desageitadamente e com evidente mau gôsto ${ }^{66}$, anular a improcedência rimática de uma pretensa

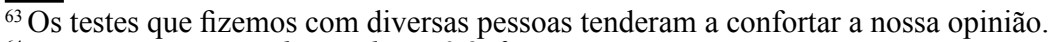

${ }^{64}$ Rima remota: $T$. g. d. v., vol. I, $n .{ }^{\circ} 87 f$.

${ }^{65}$ Rima externa e interna: T. g. d. v., vol. I, n. ${ }^{\circ} 87$ in limine, $87 \mathrm{~h}, \mathrm{i}$.

${ }^{66}$ A utilização, sem razão estética que nos pareça pertinente, na mesma sextilha, da
} 
rima remota com interpolação de versos não rimados.

Quanto às poesias «Adormecida e morta» e «Mi corazón», foram elas compostas em dísticos bieptassilábicos monórrimos, portanto de rima dita emparelhada, a primeira com 11 estrofes, a segunda com 10 estrofes $^{67}$.

Podemos, pois, dizer que a isometria, no ritmo heptassilábico, é absoluta, em Amorim de Carvalho, ou, para sermos rigoroso, quase absoluta; esta reserva resulta de duas pequenas excepções que vamos analisar.

Primeira excepção. Na poesia «Adormecida e morta», o último dístico tomou uma forma heterométrica que contrasta com os 10 precedentes, por o seu primeiro verso estar reduzido a verso simples. Transcrevemos os dois últimos dísticos:

Era a vida que trazia $\mid$ o sonho que Ela sonhou.

E sobre o abismo dos séculos | ajoelhando-se... chamou! e ficou-se à espera, absorta...

Mas, Ela, abraçada à terra, | dorme, adormecida e morta...

A segunda excepção respeita à poesia «O mistério da vida», onde as parástrofes (constituídas por versos simples) terminam, como vimos acima, por refrão:

a terrível coisa bela

que é a vida.

Ora, também há, aqui, alguma coisa a dizer. Qual a relação da forma reduzida - «que é a vida» - com o todo rítmico da poesia? Sendo o heptassílabo um ritmo de acentuação incerta, os seus quebrados têm «extensão silábica variável, por essa mesma acentuação incerta [...] mas de modo que nunca a parte que no inteiro excede o quebrado ultrapasse quatro sílabas, que é a extensão máxima do verso elementar ${ }^{68}$. Eis a razão pela qual os quebrados do heptassílabo serão de 3 e 4 sílabas métricas.

\footnotetext{
mesma expressão: «vai ficar», - é recurso infeliz do poeta.

${ }^{67}$ Rima emparelhada : T. g. d. v., vol. I, n. ${ }^{\circ} 87 \mathrm{~b}$. Versos monórrimos: T. g. d. v., vol. I, n. ${ }^{\circ}$ 87d. Dístico: T. g. d. v., vol. II, n. ${ }^{\circ} 101 \mathrm{Ia}$.

${ }^{68}$ T. g. d. v., vol. I, n. ${ }^{\circ} 23 \mathrm{~b}$.
} 
Efectivamente, todas as hipóteses acentuais no heptassílabo são as seguintes: $7^{135}, 7^{13}, 7^{14}, 7^{15}, 7^{24}, 7^{25}, 7^{35}, 7^{3}, 7^{4}$. Os heptassílabos $7^{2}$ e $7^{5}$ são ritmos imaginários, o que é explicado pela importantíssima lei da partição acentual ou da tonização rítmica: «Numa extensão silábica de mais de quatro sílabas métricas, a necessidade fisiológica da dicção e o agrado auditivo levam espontaneamente a tonizar uma ou mais sílabas átonas internas, subdividindo essa extensão silábica em grupos apoiados nas respectivas sílabas tonizadas». Assim, «toda a extensão silábica de mais de quatro sílabas tem acentuação rítmica interna (por tonicidade própria ou por tonização de sílabas átonas $) \gg{ }^{69}$. O quebrado do $7^{135}, 7^{15}, 7^{25}$ e $7^{35}$ não pode ser pentassilábico porque este ritmo forte exerceria uma influência perturbadora para o bom equilíbrio rítmico da poesia: os ritmos pentassilábicos e heptassilábicos não combinam bem entre si $^{70}$. Ficam, consequentemente, as soluções únicas das formas trissilábicas e quadrissilábicas, pois que as formas métricas monossilábicas e dissilábicas deixam mais de 4 sílabas na parte que no inteiro as excede. Em conclusão, o $2 .^{\circ}$ verso do refrão deverá considerar-se: ou como forma métrica trissilábica - que é-a-vi $(d a)$ - ou tetrassilábica - que-é-a-vi(da). É certo que, como vimos ràpidamente atrás, «os casos em que um quebrado precede imediatamente um heptassílabo ou lhe sucede imediatamente, tendo o heptassílabo um acento de acôrdo com esse quebrado, são casos eventuais ${ }^{71}$. Transcrevemos:

Da 1. ${ }^{a}$ parástrofe:
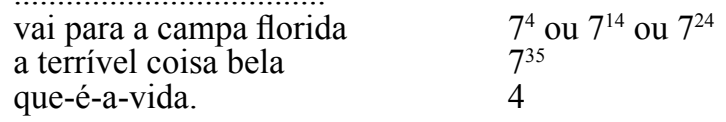

Da $2 .^{a}$ e começo da $3{ }^{a}$ :

e logo a noite se fez, $7^{24}$

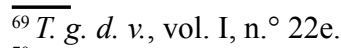

${ }^{70}$ T. g. d. v., vol. I, n. ${ }^{\circ} 63$ («Canónica das combinações heterométricas»).

${ }^{71}$ T. g. d. v., vol. I, n. ${ }^{\circ} 23 \mathrm{~b}$ in fine. 


$\begin{array}{ll}\text { e eu fiquei-me sem ver nada... } & 7^{3} \\ \text { Combalido sigo e vou } & 7^{35} \\ \text { pelas ruas, a pensar: } & 7^{3} \\ \text { Mas que é isto? E eu que sou? } & 7^{3} \\ \text { E começo a meditar } & 7^{3} \\ \text { nesta coisa incompreendida } & 7^{13} \\ \text { que me dói, que me flagela: } & 7^{3} \\ \text { a terrível coisa bela } & 7^{35} \\ \text { que-é-a-vida. } & 4 \\ & \\ \text { E de súbito parei, } & 7^{3} \\ \text { e tão triste me senti, } & 7^{3} \\ \text { que com mêdo estremeci. } & 7^{3} \\ \text { Mêdo de quê? - perguntei, } & 7^{14}\end{array}$

onde vemos que - nesta última transcrição -, nos heptassílabos, não se encontram tonizações nas $4 .^{\text {as }}$ sílabas senão no $9 .^{\circ}$ verso que precede a forma «que é a vida», e no $4 .^{\circ}$ verso que lhe sucede. Não cremos que haja, mesmo neste caso raro de grande distanciamento entre o quebrado quadrissilábico e os heptassílabos acentuados na 4. a sílaba, - não cremos que haja, neste caso, qualquer perturbação rítmica: o acôrdo rítmico fez-se satisfatòriamente. No entanto - perguntamos - não seria mais verosímil admitir que o poeta tivesse optado por uma leitura trissilábica do $2 .^{\circ}$ verso do refrão correspondente ao quebrado trissilábico que coincide, aliás, neste caso ainda, com a $1{ }^{\mathrm{a}}$ acentuação rítmica principal (fragmento inicial) do $1 .^{\circ}$ verso do dito refrão?:

a terrivel coisa bela $\quad 7^{35}$

que é-a-vida.3

Esta dicção viria reforçar uma acentuação trissilábica que se quis, talvez, predominante, no fecho refrânico de cada uma das nove parástrofes da poesia.

As duas poesias em bieptassílabos incluídas em Verbo doloroso (as já citadas «Adormecida e morta» e «Mi corazón») foram compostas, também como as bieptassilábicas de Destino, com cesuras, indiferentemente, tónicas e átonas; as razões rítmicas são aquelas que indicámos atrás para os compostos de ritmo pentassilábico. Daí, encontrarem-se, à mistura, versos como; 
Uma noite à sua porta, | passou a Morte a cantar

tão triste como as canções | que os ventos trazem do mar;

E aquela voz a adormece, | e aquela voz a matou...;

(«Adormecida e morta»)

El sufrimiento del alma | es como la primavera:

pone el corazón florido, $\mid$ con tal que el sufra y no muera.

(«Mi corazón»)

O ritmo muito forte do heptassílabo opõe-se à elisão rítmica, apela para a diálise rítmica, rejeitando a sinalefa, de modo que, qualquer que seja o tipo de cesura, átona ou tónica, é espontânea a tendência separativa dos dois componentes ${ }^{72}$. Só em «Adormecida e morta» encontramos um composto com cesura átona dobrada, $7(2)+7$ :

E sôbre o abismo dos séculos | ajoelhando-se... chamou!

Já muito pormenorizadamente estudámos, no trabalho precedentemente publicado na revista «Rhythmica», n. ${ }^{\circ}$ 3-4 (2006), o ritmo heptassilábico em composições incluídas no livro Destino editado por Amorim em 1939; de maneira que não nos alargaremos agora em considerações gerais respeitantes a aspectos versificatórios por nós abordados naquele estudo. O que há a reter, depois de leitura atenta do conjunto das poesias de ritmo heptassilábico de Destino e de Verbo doloroso (1942), é que aquelas poucas razões que encontráramos no primeiro desses livros para comentários, que fizéramos, de ordem técnico-melódica, - essas poucas razões nem já existem ou existem também muito marginalmente em Verbo doloroso. No conjunto daquelas sete poesias em ritmo heptassilábico que acabamos de estudar, podemos apenas reparar em:

Gargalhar de ecos aflitos

(«A filha do sineiro»)

$\overline{{ }^{72} T .}$ g. d. v., vol. I, n. ${ }^{\circ} 27$. 
com duas sílabas seguidas acentuadas, que nos parece menor perfeição melódica. As amplitudes de 4 ou 5 sílabas átonas verificam-se em dois casos («Ausência e amor», «A filha do sineiro»):

sempre no seu coração;

nos ares tumultuando;

onde (como explica a lei da partição acentual) se verifica espontaneamente a tonização da sílaba seu (aliás, com certa tonicidade própria, apesar de débil), levando, assim, com naturalidade, para essa sílaba, a segunda acentuação rítmica do verso; e onde também se verifica, por imposição da mesma lei, a tonização de «uma ou mais sílabas átonas internas» de uma «extensão silábica de mais de quatro sílabas métricas» (tu ou mul, de tumultuan$d o)$ : são «como que acentos forçados de partição rítmica». $\mathrm{Na}$ poesia «Cigana», o mesmo caso, onde a tonicidade própria ou natural surge apenas na 5. ${ }^{\mathrm{a}}$ sílaba, impondo, consequentemente, a tonização forçada das $3 .^{\mathrm{a}}$ ou $2 .^{\mathrm{a}}$ ou $1 .^{\mathrm{a}}$ sílabas (nesta última, talvez reforçada com «pausa compensatória» $\left.{ }^{73}\right)$ :

e que inutilmente abertas;

e que inutilmente abertas;

$e^{\mid}$que inutilmente abertas.

Num verso simples (de «Cigana») e num hemistíquio (de «Mi corazón»), a seguir transcritos, - podemos legitimamente considerar que os ritmos soarão ligeiramente comprimidos?:

que ia pra um país distante;

... | yo orgulloso como un Dios

(que i-a-praum; yo or-gu-llo-so-co-mo un $)^{74}$.

De tudo o que acabamos de escrever, deverá concluir-se que o estudo atento das poesias de ritmo lírico de Verbo doloroso, revela a maestria de Amorim de Carvalho na composição dos ver-

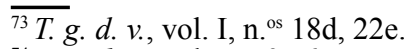

${ }^{74}$ T. g. d. v., vol. I, n. ${ }^{\circ} 76$. 
sos, não só do ponto de vista estritamente rítmico, mas também pela grande pureza melódica que o poeta sabe transmitir-lhes.

Damos por terminados os nossos estudos sobre o ritmo lírico nas primeiras obras poéticas publicadas em livro por Amorim de Carvalho. Pretendêmos, com eles, levar o esfôrço de análise até à exaustão, até esgotar as dificuldades que - nesse domínio do conhecimento estético: o do ritmo na expressão poética - pode suscitar a obra de um grande poeta. Nós consideramos, por outro lado, que, sem o arrimo da teoria do ritmo verbal de que também Amorim de Carvalho foi o notabilíssimo iniciador e sistematizador, não seria possíel atingir a pertinência e a qualidade analítica que vimos dando aos nossos trabalhos sobre Versificação.

$$
* * *
$$

NOTA BENE. Aproveitamos a oportunidade para corrigir as principais gralhas que se intrometeram no nosso estudo $O$ ritmo na poesia de Amorim de Carvalho in «Rhythmica», n. ${ }^{\circ}$ 3-4 (2006). Pág. 14: separar as estrofes do soneto. Notas ${ }^{16} \mathrm{e}^{18}$, ler: $12^{48}, 5^{2}, 5^{1}$ ou 13 ou $3,5^{1-13-3}, 5^{2}+5^{2}$, no ar, Abri-lhe, $8^{6}, 8^{4}, 8^{26}+8^{4}, 8^{26}$. Pág. 27 , ler: $5^{2}$; caso. Págs. 27 a 38: colocar os

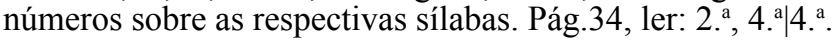

Colline de la Boissière, Rosny-sous-Bois (França), 2008 
